\title{
Hydrocarbon and aqueous inclusions in minerals: a review of analyses and interpretations for Paleozoic rocks in Poland
}

\author{
Katarzyna JARMOŁOWICZ-SZULC ${ }^{1, *}$ \\ 1 Polish Geological Institute - National Research Institute, Rakowiecka 4, 00-975 Warszawa, Poland
}

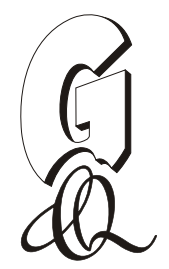

Jarmołowicz-Szulc, K., 2021. Hydrocarbon and aqueous inclusions in minerals: a review of analyses and interpretations for Paleozoic rocks in Poland. Geological Quarterly, 65: 56, doi: 10.7306/gq.1625

Associate Editor: Dariusz Więcław

Two decades of microthermometric studies of fluid inclusions within cements of Paleozoic sedimentary rocks in Poland are reviewed. The inclusions contain palaeofluids of variable composition: aqueous, brine, and hydrocarbon. They may be primary and/or secondary in origin and have one, two or more phases. They display visual fluorescence in blue, sometimes yellow to red (oil) or dull blue (one phase, methane) colours, or do not fluoresce at all. Based on the fluorescence characteristics in ultraviolet light, the inclusions' hydrocarbons infill character may be estimated. The homogenization temperatures, which correspond to the minimum estimate of the trapping temperatures in the minerals, show variability in respect to the geological history of the area studied. They point to different geological stages in relation to the basin's burial evolution. Microthermometric analyses enable wider interpretation due to the combination of studies of both hydrocarbon and aqueous inclusions. The presence of oil and/or gas in inclusions is proof of the occurrence and/or migration of oil and gas in the rocks of a region.

Key words: fluid inclusions, hydrocarbons, Paleozoic, Baltic Sea, Polish Lowlands.

\section{INTRODUCTION}

Many publications on fluid inclusions (FI) in minerals in sedimentary basins discuss the temperature, physical and chemical conditions of diagenesis and catagenesis, and the dependence of hydrocarbon compositions on pressure and temperature (P-T) conditions of hydrocarbon fields, hydrocarbon phase compositions with depth and the estimation of the processes responsible for hydrocarbon expulsion from source rocks (e.g., Kozłowski, 1982; Roedder,1984; Mc Limans, 1987; Mc Limans and Videvitch, 1987; Bodnar, 1990; Goldstein and Reynolds, 1994; Munz et al., 1995; Kalyuzhnyi and Sachno, 1998; Dudok and Jarmołowicz-Szulc, 2000; George et al., 2001). Recently a review of petroleum-bearing inclusions and their use to trace petroleum systems worldwide has been published by Volk and George (2019), and recent publications concern the relationship between fluorescence properties of oil inclusions and their thermal maturity (Ping et al., 2019a, b, 2020).

With this progress in mind, an updated review of fluid inclusion studies from different sedimentary geological environments in Poland is pertinent and is the aim of the present paper.

\section{*E-mail: kjar@pgi.gov.pl}

Received: February 2, 2021; accepted: November 10, 2021; first published online: December 7, 2021
The study area covers much of the territory of Poland and is subdivided into the different Paleozoic sedimentary basins, with ages spanning from the Cambrian to the Permian (Fig. 1). Hydrocarbon-bearing inclusions $(\mathrm{HCFI})$ have been observed there in some regions (Fig. 1: areas $\mathrm{A}, \mathrm{E}$ ). $\mathrm{HCFI}$ are present in minerals in the regions adjacent to the Baltic shelf and Baltic coast (Jarmołowicz-Szulc, 1998, 2001a, 2015; Fig. 1: areas A, D) through the NW and central parts of the Polish Lowlands (Jarmołowicz-Szulc, 1999a, b, 2015; Fig. 1: areas E, F, B, C, D), up to the Carpathian Foredeep and the Carpathians (Dudok and Jarmołowicz-Szulc, 2000; Jarmołowicz-Szulc and Dudok, 2005; Jarmołowicz-Szulc et al., 2008, 2012; Jankowski and Jarmołowicz-Szulc, 2009; Jarmołowicz-Szulc, 2009, 2015).

This study characterizes the fluids present during or after the formation of basins of different ages in Poland. These fluids may be trapped in diagenetic and metamorphic minerals and so reflect diagenetic changes in the basins. The minerals formed within the basins, such as carbonates, quartz, fluorite and anhydrite, some of which bear oil- and/or gas inclusions, record hydrocarbon migration through the strata. The co-occurrence of gas-bearing and/or hydrocarbon-bearing inclusions, and aqueous inclusions, enables estimation of pressure and temperature conditions during their trapping (Fig. 2).

Studies on liquid-gas inclusions are based on the assumption that the minerals that fill pore space in sedimentary rocks may trap small portions of basin fluids in their microfissures during their crystallization (Roedder, 1984). Such inclusions are relics of palaeofluids that may no longer exist. When we study fluid inclusions in the laboratory by heating and/or freezing 


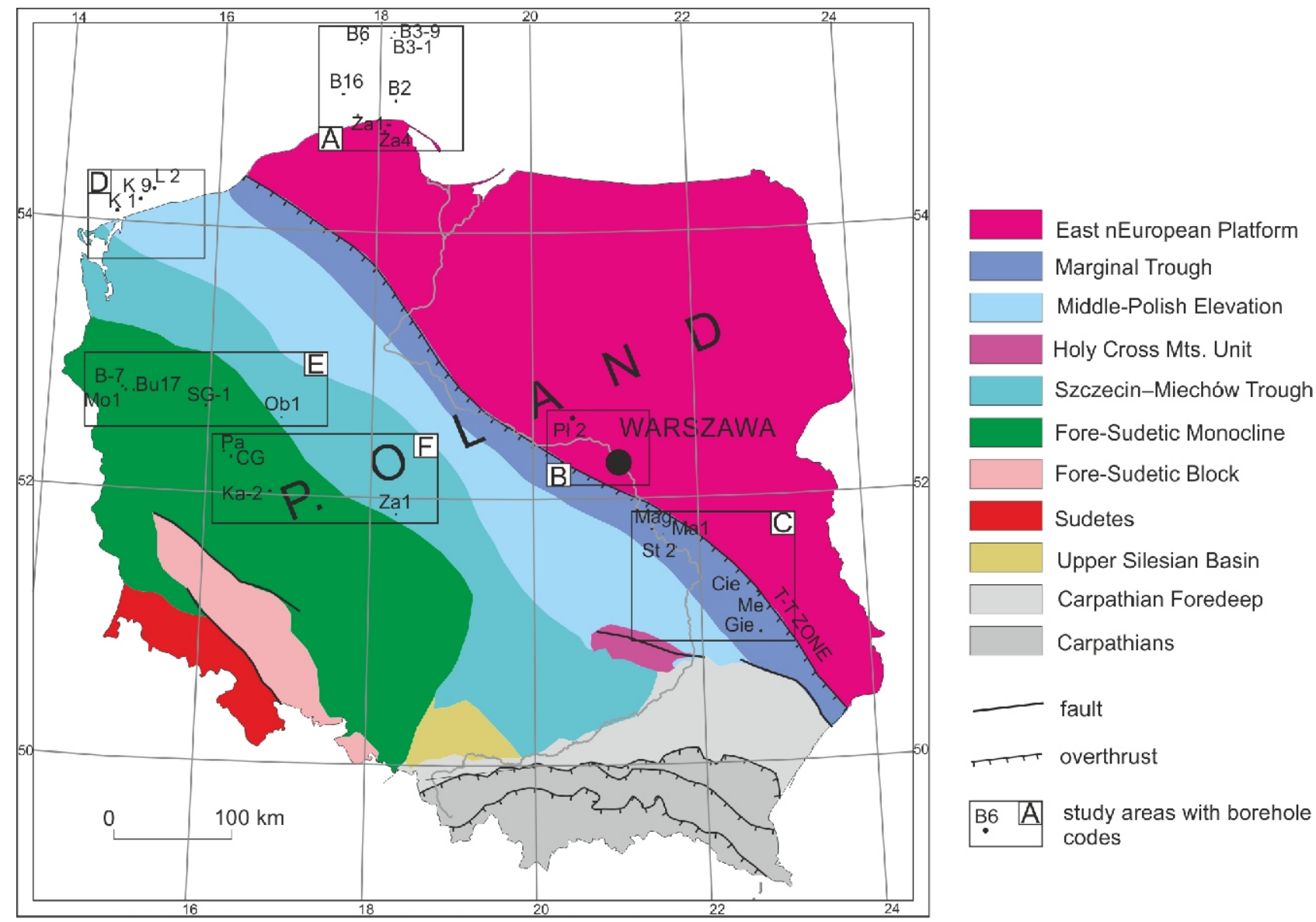

Fig. 1. Geographic location of the boreholes studied in relation to the geological structure of Poland (geology partly based on maps by Pożaryski, 1968; Nawrocki and Becker, 2020; generalized and modified)

A - onshore and offshore Baltic Sea area; B - central Poland (Warsaw Trough); C - Lublin area; D - western Baltic Sea area; E - Polish Lowlands (Wielkopolska); F - Polish Lowlands (Fore-Sudetic Monocline); rectangles mark location of boreholes listed in Table 1

them, based on their temperature behaviour we can characterize their fluid contents and therefore reconstruct the primary conditions of mineral formation and determine the composition and the density of the palaeofluids. The stability of the primary volume and composition of the fluid in inclusions is, however, a major requirement and is the basis of the application of the $\mathrm{FI}$ study method. This condition is extremely difficult to fulfil in sedimentary rocks, which could have been deeply buried and/or uplifted. Different minerals that fill the pore space (quartz, carbonates, sulphates) display different susceptibility to changes caused by the external conditions of increased temperatures and pressures. Quartz is considered the most resistant mineral whereas carbonates and sulphates are more susceptible to diagenetic and metamorphic alteration. This is why FI results obtained from quartz are the most reliable (Goldstein and Reynolds, 1994; Jarmołowicz-Szulc, 1998), provided that the formation of quartz overgrowths, for example, has not been a result of recrystallization of less stable quartz or silica phases (Goldstein and Rossi, 2002).

\section{BRIEF DESCRIPTION OF GEOLOGICAL SETTING}

Figure 1 shows the six study areas. Within these, the rocks studied, from the Cambrian to the Permian, were reached by deep boreholes (listed in Table 1 with their codes, and generally marked on Figure 1).
In the north of Poland (Fig.1: area A), Lower Paleozoic strata lie on Precambrian basement. Lower and Middle Cambrian deposits are overlain by Silurian, Permian and Mesozoic strata (Jarmołowicz-Szulc, 1998, 2001; Sikorska 2000). Two transgressive-regressive cycles have been recognized in the cover of the East European Craton (Jaworowski, 1997). The Middle Cambrian sandstones represent the petroleum reservoir there, of the Paradoxides paradoxissimus and Eccaparadoxides oelandicus biozones.

In the central part of the country, close to the Marginal Trough near Warsaw (Fig. 1: area B), the Warsaw Trough is located. Its area may be divided into three structural blocks, including the Płońsk block with its Ordovician deposits (Marek, 1983). The trough is developed on the marginal part of the East European Platform, dipping towards the SW and being separated by the Teisseyre-Tornquist (TT) Zone from the platform.

The Lublin Basin (Fig. 1: area C) is situated in SE Poland. It is located in the southeastern part of the Polish Lowlands, close to the Teisseyre-Tornquist Zone, which in Poland separates the Paleozoic-Mesozoic and the Precambrian platforms. Devonian rocks were sampled in this area, Fammenian in age and comprising lime mudstones-wackestones (Radlicz, personal information 1997; Narkiewicz, 2011). They represent the thickest part of their development and a strong facies gradient, formed in deep water facies in a subsiding basin.

The Lublin graben to the south is an elongated NW-SE structural unit. The base of the Carboniferous in the basin is of 


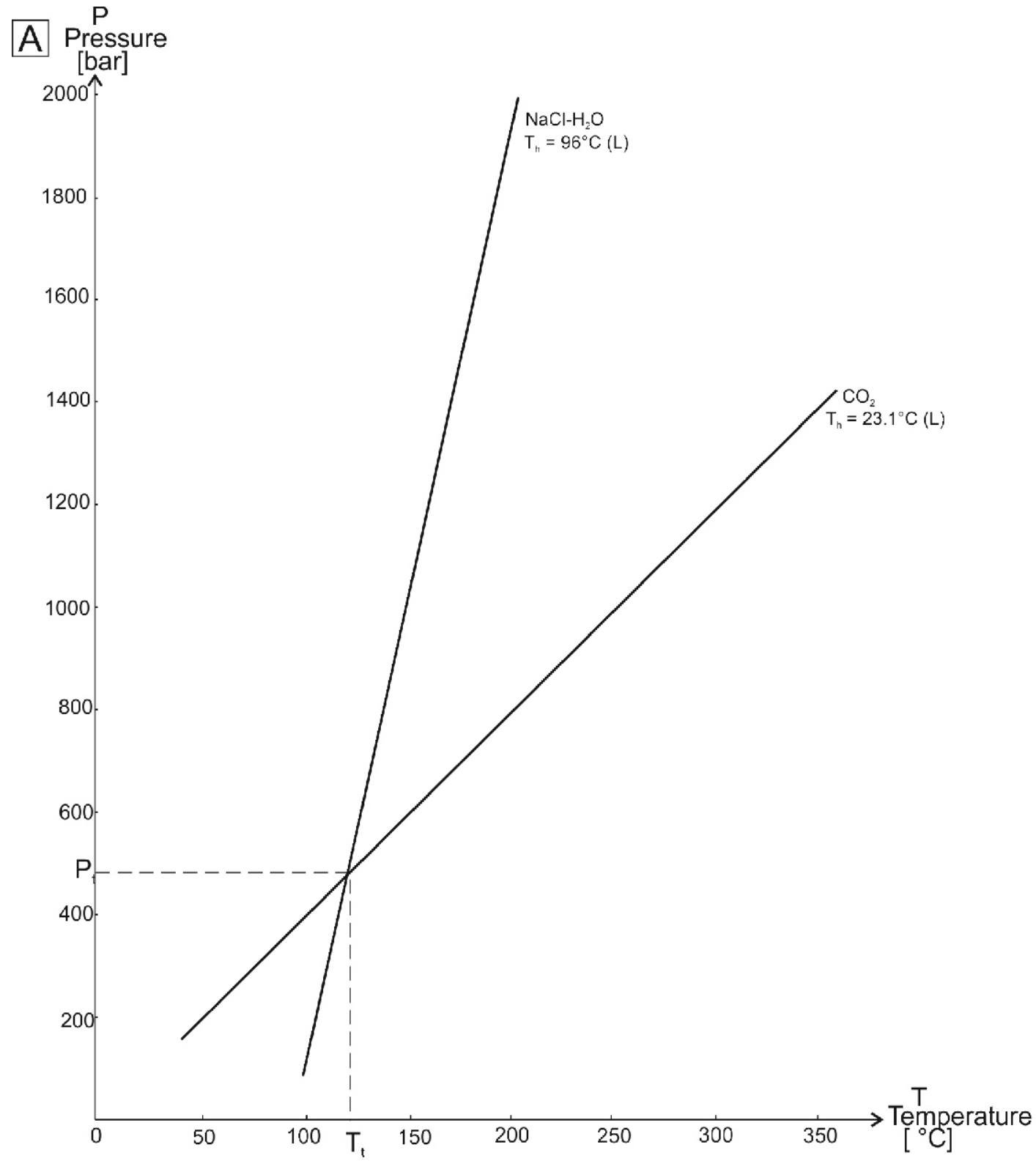

B

$$
\begin{aligned}
& \text { P } \\
& \text { Pressure } \\
& \text { [bar] }
\end{aligned}
$$

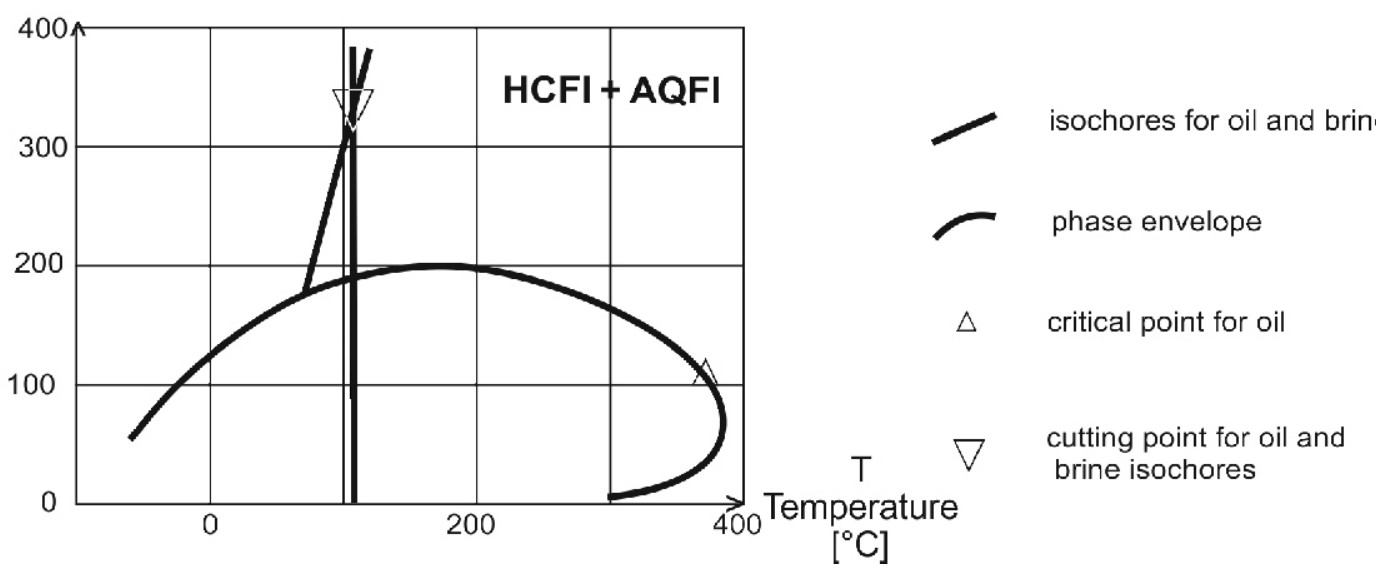

Fig. 2. Pressure-temperature (P-T) estimation using the crossing isochores method

A - estimation of trapping conditions for brine and carbon dioxide (K1-1/86 borehole, the Baltic Sea, FI in quartz, depth $3107.7 \mathrm{~m}$ ); $\mathbf{B}$ - estimation of trapping conditions for brine and oil, based on confocal and microthermometric results (after Jarmołowicz-Szulc, 2001a) 
List of boreholes and number of mineral samples analysed for fluid inclusions

\begin{tabular}{|c|c|c|c|c|c|c|}
\hline Borehole & Code & $\begin{array}{l}\text { Depth } \\
\text { [m] }\end{array}$ & Lithology & $\begin{array}{l}\text { Location in } \\
\text { Figure } 1\end{array}$ & $\begin{array}{l}\text { Number of } \\
\text { samples } \\
\text { studied }\end{array}$ & References \\
\hline \multicolumn{7}{|c|}{ Cambrian } \\
\hline Żarnowiec IG 1 & Ża1 & $2650-3000$ & Sandstones & A & 40 & [1], [2] \\
\hline Żarnowiec IG 4 & Ża4 & 2739.8 & Sandstones & A & 35 & [1], [2] \\
\hline B2-1/80 & B2 & $2466.8-2529.9$ & Sandstones & A & 6 & {$[3],[2]$} \\
\hline B6-2/82 & B6 & $1460.7-1509.5$ & Sandstones & A & 4 & [3], [2] \\
\hline B16-1/85 & B16 & $1855.6-2150.5$ & Sandstones & A & 10 & [3], [2] \\
\hline B3-1/95 & B3-1 & $1413.2-1441.8$ & Sandstones & $\mathrm{A}$ & 13 & [3] \\
\hline B3-9/96 & B3-9 & 1415.5 & Sandstones & A & 1 & [2] \\
\hline \multicolumn{7}{|c|}{ Ordovician } \\
\hline Płońsk IG 2/2A & $\mathrm{P} \nmid 2$ & $3522.15-3530.7$ & Limestones & $\mathrm{B}$ & 5 & [4] \\
\hline \multicolumn{7}{|c|}{ Devonian } \\
\hline Giełczew IG 5 & Gie & 1955.2 & Carbonates & C & 1 & [2] \\
\hline Mełgiew 2 & $\mathrm{Me}$ & $3745.2-3848.2$ & Carbonates & $\mathrm{C}$ & 5 & [5], [2] \\
\hline Ciecierzyn 8 & Cie & $3815.1-3869$. & Carbonates & C & 5 & [5], [2] \\
\hline \multicolumn{7}{|c|}{ Carboniferous } \\
\hline Stężyca 2 & St 2 & $1470.0-2784.5$ & Sandstones & C & 38 & [6] \\
\hline Maciejowice IG 1 & Ma 1 & $1846.0-3504.5$ & Sandstones & $\mathrm{C}$ & 5 & [6] \\
\hline Magnuszew IG 1 & Mag & $2102.0-3003.5$ & Sandstones & C & 5 & [6] \\
\hline K1-1/86 & K 1 & $3100-3402$ & Sandstones & $\mathrm{D}$ & 5 & [6] \\
\hline K9-1/89 & K 9 & 3242-3963 & Sandstones & $\mathrm{D}$ & 5 & [6] \\
\hline L2-1/87 & L 2 & $2187.0-2620.5$ & Sandstones & $\mathrm{D}$ & 1 & [6] \\
\hline Objezierze IG 1 & Ob 1 & $4621.1-5090.0$ & Sandstones & $E$ & 10 & [5] \\
\hline Zakrzyn IG 1 & Za 1 & $4545.6-4905.4$ & Sandstones & $\mathrm{F}$ & 20 & [5] \\
\hline Katarzynin 2 & $\mathrm{Ka}-2$ & $2370.4-2640.0$ & Sandstones & $\mathrm{F}$ & 20 & [5] \\
\hline \multicolumn{7}{|c|}{ Permian } \\
\hline Paproć IG 5 & $\mathrm{~Pa}$ & $2627.5-2777.8$ & Sandstones & $\mathrm{F}$ & 20 & [7], [8], [9] \\
\hline Cicha Góra 2 & CG & $2708.7-2714.8$ & Sandstones & $\mathrm{F}$ & 30 & [9] \\
\hline Mostno 1 & Mo1 & $3027.5-3357.35$ & Carbonates & $E$ & 25 & [10] \\
\hline Barnówko 7 & B 7 & 3123.35 & Carbonates & $E$ & 10 & [11] \\
\hline Buszewo 17 & Bu 17 & 3133.45 & Carbonates & $E$ & 18 & [11] \\
\hline Sowia Góra 1 & SG-1 & 3256.34 & Carbonates & $E$ & 6 & [12] \\
\hline
\end{tabular}

[1] Jarmołowicz-Szulc (1998); [2] Current study; [3] Jarmołowicz-Szulc (2001); [4] Jarmołowicz-Szulc and Wołkowicz (2018); [5] Jarmołowicz-Szulc (2003); [6] Kozłowska and Jarmołowicz-Szulc (2009); [7] Maliszewska et al. (1997, 2003); [8] Jarmołowicz-Szulc (2018); [9] Jarmołowicz-Szulc (1999a, b); [10] Jarmołowicz-Szulc et al. (2020); [11] Jarmołowicz-Szulc et al. (2021); [12] Jarmołowicz-Szulc and Jasionowski (2009)

Namurian age (Kozłowska and Jarmołowicz-Szulc, 2009). The thickness of the Carboniferous deposits developed as sandstones increases towards the SE from $\sim 370$ to $>1600 \mathrm{~m}$ (Kozłowska and Jarmołowicz-Szulc, 2009).

The present offshore part of the Pomerania basin (Fig. 1: area D) is characterized by siliciclastic-evaporitic deposits, with subordinate carbonates. In the Early Carboniferous the Pomerania area may have been located close to the East European Craton, though that is not its present position (Matyja, 2006). Three types of lithological successions may be distinguished: sandstones, slates and hybrid deposits. Sandstones comprise potential levels for tight gas accumulations, while the schistose rocks have potential for shale gas (Podhalańska et al., 2019).

In the south of the country, Permian Rotliegend deposits in the Fore-Sudetic Monocline (Fig. 1: area E) form two distinct sucessions (Maliszewska et al., 2003); they differ genetically and have different distributions. They are unequally recognised in boreholes is not equal because of differences in depth. The upper sedimentary succession of conglomerates, sandstones and mudstones represents the Upper Rotliegend. The lower succession is represented by Lower Rotliegend epiclastic deposits.

In the western part of Poland in the Wielkopolska area (Fig. 1: area F), the carbonates of the Upper Permian (Zechstein) Main Dolomite (Ca2) include shallow platform and basin facies (Jaworowski and Mikołajewski, 2007). They form the richest oil and gas-bearing carbonate reservoir in Poland (Karnkowski, 1993; Górski and Trela, 1997). The Ca2 carbonate platform is built of a succession of oolitic, oncolytic and peloidal grainstones/packstones, and lagoonal mudstones, up to $80 \mathrm{~m}$ thick. It is developed on top of the older sulphate platform. Dark, thin laminated deep marine mudstones were deposited in the basin at the same time. 


\section{ANALYTICAL BACKGROUND}

A range of petrological, mineralogical and geochemical techniques have been applied to sedimentary basins in Poland, that complement the fluid inclusion analyses. Petrographic and $\mathrm{FI}$ analytical procedures always comprise several stages, typically: (1) sampling and preparation of the rock samples, (2) microscopic evaluation of the material as regards organic matter minerals and inclusions, (3) detailed microscopic determinations (microthermometry), (4) geochemical analyses, and auxiliary studies. Analytical steps undertaken to study both fluid inclusions and whole rocks/minerals include:

X-Ray Diffraction (XRD) determinations were performed to determine the bulk mineralogical composition of the rock samples by the powder method using a Philipps X' Pert PW 3020 with respect to international standards. Detailed methodology may be found elsewhere (e.g., Kozłowska, 2004). The reflectance of the organic matter was determined both on double-sided polished sections (approximate data) and on polished slabs.

SEM analyses of mineral parageneses were conducted in uncovered carbon-plated thin sections using two electron scanning microscopes: JSM-35, JEOL or 1430, LEO, combined with EDS ISIS.

\section{PREPARATION AND ANALYTICAL TECHNIQUES} FOR FLUID INCLUSION STUDIES

Over 300 samples were collected for fluid inclusion (FI) studies (Table 1) and were prepared for analyses using standard preparation techniques (Shepherd et al., 1985; Jarmołowicz-Szulc, 2000). Double-sided-polished thin sections, $0.1-0.2 \mathrm{~mm}$ thick, were obtained through low-temperature polishing of rock slabs. General microscopic observations were made with a polarizing microscope both in transmitted and reflected ultraviolet (UV) light. These comprised a microscopic analysis of fluid inclusions (Leitz Orthoplan), fluorescence studies and microphotography (Nikon microscope and UV device), and microthermometric analyses. The latter included heating and freezing using a Fluid Inc. System, mounted on a Leitz Orthoplan microscope and/or the Linkam equipment mounted on a Nikon microscope with digital microphotography. In the case of the Cambrian and Carboniferous quartz cements (overgrowths) cold cathodoluminescence studies (CCL 8200 $m K 3$ ) were performed on slabs parallel to the fluid inclusion wafers aiming at locating of rims on detrital grains.

The Fluid Inc. System and the Linkam stage were calibrated against melting temperatures of pure chemicals and phase transitions in synthetic fluid inclusions (SYNFLINC standards, Reynolds, 1993). The uncertainty limits are $0.2^{\circ} \mathrm{C}$ below $-100^{\circ} \mathrm{C}, 0.1^{\circ} \mathrm{C}$ between -100 and $+100^{\circ} \mathrm{C}$, and $0.2^{\circ} \mathrm{C}$ above $100^{\circ} \mathrm{C}$. The type of $\mathrm{Fl}$-hosting mineral is a pointer towards either a freezing-heating or heating-freezing mode. Fluid inclusions in quartz were studied by heating after freezing, while those in carbonates were studied first by heating prior to freezing (Roedder, 1984; Shepherd et al., 1985; Samson et al., 2003). Thermometric studies in the heating mode generally lead to the determination of temperatures of mineral crystallization since it has been assumed that the homogenization temperature of the primary aqueous inclusions represents a minimum temperature of fluid trapping during mineral precipitation (Roedder, 1984).

Estimation of the pressure and temperature conditions of the formation of minerals is based on the crossing isochore technique using coexisting methane and aqueous inclusions, following the method introduced by Kalyuzhnyi (1982; Fig. 2A), or using petroleum and aqueous inclusions following the method by Applin et al. (1999; Fig. 2B). Isochores for simple components were calculated with both the Flincor software (Brown, 1982) and FLUIDS package (Bakker, 2003; Bakker and Brown, 2003).

Fluorescence of the organic matter and/or fluid inclusions was induced by ultraviolet reflected light in plates prepared for microthermometry studies. Long-wavelength light $(368 \mathrm{~nm})$ was provided by a $100 \mathrm{~W}$ mercury lamp and a set of filters. Since the end of the 20th century, fluorescence studies have been conducted as a rule in research on fluid inclusions in minerals in sedimentary rocks (e.g., Jarmołowicz-Szulc, 2000, 2001a).

\section{CONFOCAL LASER SCANNING OF INCLUSIONS}

The Confocal Laser Scanning Microscopy method (CLSM) has a wide application to hydrocarbon inclusions (Applin et al., 1999 and references therein). These studies have been performed by the Newcastle Research Group at the University of Newcastle upon Tyne, Great Britain.

Determination of petroleum composition in inclusions in the diagenetic cements from oil reservoirs was important for two reasons: (1) in combination with microthermometry these data may result in the estimation of oil during secondary migration and the filling of the field; (2) exact analysis of composition is necessary for PVT modelling of oil.

Two-sided polished samples glued to a glass slide were analysed with CLSM. Each step corresponded to an individual oil inclusion. The inclusion was scanned, photographed, and digitally recorded. A vertical "cut" of the object to slices of equal height has been the basis of the analysis. Based on the confocal results for oil and microthermometry, trapping conditions were estimated (Fig. 2B). The first results on Polish samples by this method were reported in 2001 (Jarmołowicz-Szulc, 2001a).

\section{STABLE ISOTOPE GEOCHEMISTRY}

Stable isotope studies (O’Neil, 1979) were conducted by classical methods for quartz and calcite, collaboratively. Some isotope point analyses of the oxygen in quartz were performed in the USA (Tempe, Arizona), according to the procedure described by Hervig et al. (1992). Other quartz samples were analysed in Canada (Newfoundland University). Silicate and oxide samples were reacted with $\mathrm{BrF}_{5}$ at $\sim 650^{\circ} \mathrm{C}$ in nickel bombs following the procedures described by Clayton and Mayeda (1963). The fluorination reaction converts the $\mathrm{O}$ in the mineral(s) to $\mathrm{O}_{2}$ gas, which is subsequently converted to $\mathrm{CO}_{2}$ gas using a hot $\mathrm{C}$ rod. Isotopic analyses were performed on a Finnigan MAT Delta, dual inlet, isotope ratio mass spectrometer. The data are reported in the standard delta notation as per mil deviations from VSMOW. External reproducibility is $\pm 0.19 \%$ (1 sigma) based on repeat analyses of the internal white crystal standard (WCS). The value for NBS 28 is $9.61 \pm 0.10 \%$ o (1 sigma). The $\delta^{18} \mathrm{O}$ was calculated based on the Sheppard standard formula (1986).

Analyses of the isotope composition of oxygen and carbon in calcite were mostly conducted in the Isotope Laboratory of the Maria Curie-Skłodowska University at Lublin, Poland. The method has been described by Durakiewicz and Hałas (1994) and Durakiewicz (1996). Gaseous carbon dioxide was released from carbonates during reaction with phosphoric acid. Isotope measurements of carbon and oxygen were conducted in a modified MI1305 mass spectrometer with a measurement precision of $\pm 0.08 \%$ ( 1 sigma). Measurements were made with reference to international standards (Durakiewicz, 1996). 
Carbonate temperatures of formation were calculated based on the carbonate isotopic composition $\left(\delta^{18} \mathrm{O}\right.$ PDB $)$ using the Anderson and Arthur (1983) fractionation formula:

$\mathrm{T}\left({ }^{\circ} \mathrm{C}\right)=16.0-4.14\left(\delta^{18} \mathrm{O}_{\text {carb }}(\mathrm{V}\right.$-PDB $)-\delta^{18} \mathrm{O}_{\text {water }}(\mathrm{V}$-SMOW $\left.)\right)+$ $0.13\left(\delta^{18} \mathrm{O}_{\text {carb (V-PDB })}-\delta^{18} \mathrm{O}_{\text {water }(\mathrm{V}-\mathrm{SMOW}))^{2}}\right.$

Quartz formation temperatures were calculated based on the isotopic composition ( $\delta^{18} \mathrm{O}_{\text {SMOW }}$ ) using the program Palaeotemperatures $\left(\mathrm{SiO}_{2}\right)$ according to Clayton et. al. (1972).

Point oxygen and carbon isotopic analyses of carbonates were made for the Rotliegend cements in co-operation with the Institute for Energy Technology in Norway with a laser spectrometry method. Methodological details of such analyses are given elsewhere (e.g., Munz et al., 1995), while results for the Paproć-Cicha Góra area are in Jarmołowicz-Szulc (1998, 1999a, 2009).

RAMAN ANALYSIS

Raman analysis is an important technique for studying inclusion content and character (Burrus, 2003; Frezzotti et al., 2012), used occasionally for the material described here. Analyses were conducted in several scientific centres, on various equipment. Samples for Raman determinations were prepared either as standard uncovered thin sections for petrological studies or special, double sided - polished sections for fluid inclusion analyses. The individual samples were placed in the Raman microspectrometer e.g., at DXB 2 at the AGH University of Science and Technology in Kraków. The use of a $532 \mathrm{~nm}$ laser (green) at 3 to $8 \mathrm{~mW}$ on the sample surface enables spectra formation. Point spectra were excited within 20 to 50 seconds depending on the sample. In the confocal mode, spectra from a sample of 2 micrometres diameter may be observed, though this is more time-consuming (Kozłowska et al. 2021).

Raman spectra observed on the computer monitor were recorded. Individual maxima were identified by their wavelength and compared to identification tables (Frezzotti et al., 2012; Fig. 3). In case of gas-filled inclusions, the field of the spectra may be measured and the percentage of phases can be calculated based on the mutual relationships of the components identified. Such a detailed composition may be further used for PVT calculations when specialized computer programs are used (Bakker, 2003; Bakker and Brown, 2003).

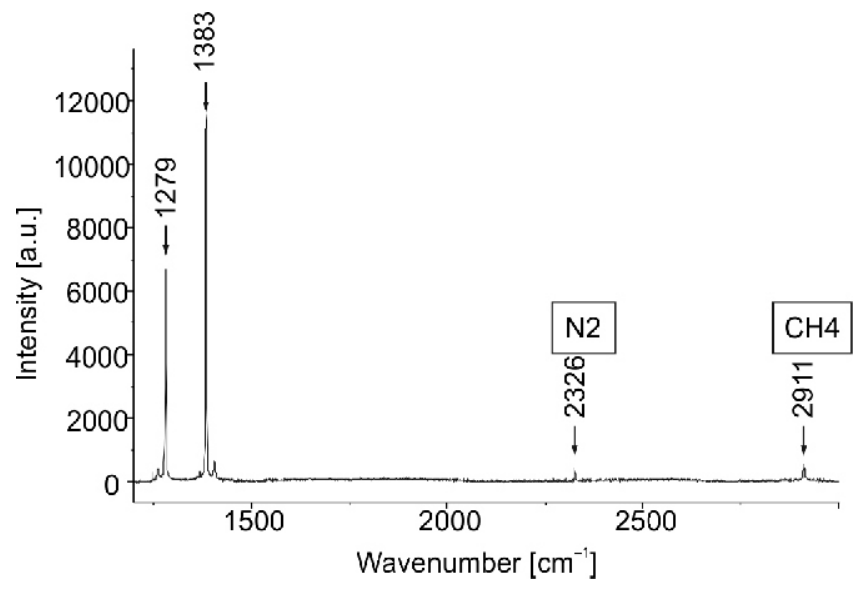

Fig. 3. Raman spectrum identifying methane and nitrogen peaks (FI in calcite, based on Kozłowska et al., 2021)

\section{RESULTS}

The geological structure of Poland, with more than the half of the country built of sedimentary rocks, enable detailed study of the different sedimentary basins (Fig. 1). The rocks were accessed by drilling and within different programs (see: e.g., Jarmołowicz-Szulc, 1998; Maliszewska and Kuberska, 1996; Maliszewska et al., 1997; Kozłowska, 2004; Kuberska, 2004). The study material came from the Cambrian (the Baltic Sea area, onshore and offshore), the Ordovician (the Warsaw Trough), the Devonian (the Lublin Basin area), the Carboniferous (the Lublin Basin area, western Baltic Sea area, the Fore-Sudetic Monocline and the Wielkopolska region ) and the Permian (the Fore-Sudetic Monocline and the Wielkopolska region; Fig. 1: areas A-F).

\section{CAMBRIAN}

Cambrian deposits were analysed in boreholes in the northern part of Poland, offshore and onshore in the Żarnowiec region and on the Łeba Elevation (Fig. 1: area A; Jarmołowicz-Szulc, 1998, 2001a; Sikorska, 2000).

\section{ONSHORE BALTIC SEA}

Results: FI in quartz arenites in the Żarnowiec region (Żarnowiec IG 1 and IG 4 boreholes) occur in late quartz cement overgrowths around detrital grains, and in secondary quartz healing of fissures (Jarmołowicz-Szulc, 1998). Two types of two-phase fluid inclusions were observed: aqueous and hydrocarbon FI. The latter were distinguished based on their white-blue visual fluorescence, which nowadays may be considered as "blue" following suggestions by Ping and co-workers (Ping et al., 2020). Two-phase non-fluorescent inclusions homogenized to liquid at temperatures of $87-90^{\circ} \mathrm{C}$ and $107^{\circ} \mathrm{C}$, fluid salinity was $\sim 8 \mathrm{wt} . \% \mathrm{NaCl}$ eq. Two-phase fluorescent inclusions displayed homogenization in the interval $74-110^{\circ} \mathrm{C}$. One-phase inclusions were observed, too, in the cement, the isotopic composition $\left(\delta^{18} \mathrm{O}\right)$ of which was ranged from 20 to $28 \%$ SMOW (Jarmołowicz-Szulc, 1998).

Interpretation: The Middle Cambrian sandstones in the Żarnowiec region contain aqueous fluid inclusions (AQFI) and hydrocarbon fluid inclusions (HCFI) in quartz cements, respectively representing early and late stages of basin evolution. The one-phase inclusions occur in early cement, which crystallised in conditions corresponding to low temperatures and precipitation from waters close to the meteoric water. High-temperature nonfluorescent two-phase fluid inclusions (AQFI) occur in late quartz cement that commonly cuts detrital grains and the intergranular space. Late cementation occurred at temperatures of $\sim 100^{\circ} \mathrm{C}$ from waters of heavier isotopic composition and complex chemistry. The fluorescing two-phase inclusions were either trapped in the filling of veinlets cutting detrital grains or in less regular infills of micro-fissures. They were related to the late cement, similarly to the inclusions at the boundary between the detrital grain and the authigenic quartz overgrowth. The fluids in the basin are mature oil, with $\mathrm{API}$ (American Petroleum Institute) gravity values of $\sim 39-40^{\circ}$ and $\mathrm{NaCl}-\mathrm{H}_{2} \mathrm{O}$ brines. Co-trapping of the brine and oil in the Zarnowiec area occurred in conditions of $\sim 135^{\circ} \mathrm{C}$ and 500 bar (Jarmołowicz-Szulc, 1998). 
OFFSHORE BALTIC SEA

Results: Only some fluid inclusions in the quartz cements in the wells of the Łeba Elevation were seen to be fluorescent, of size 1-10 $\mu \mathrm{m}$ while non-fluorescent Fls were 1-3 $\mu \mathrm{m}$ across. Fluid inclusions displayed either primary or secondary character. Two-phase inclusions occur at the boundary of detrital and authigenic quartz, in the early cement and in the late filling of microfissures (Fig. 4A, B). Many Fls displayed fluorescence in blue colours in the UV range. Those fluorescent inclusions (HCFI) are characteristic of the late filling of fissures. Two-phase HCFI showed homogenization in the interval from 60 to $>100^{\circ} \mathrm{C}$ (Jarmołowicz-Szulc, 2001a). AQFI displayed two ranges of homogenization temperatures. One-phase inclusions occurring in the early quartz cement were trapped at $\sim 50^{\circ} \mathrm{C}$ (compare: Goldstein and Reynolds, 1994). The second group of AQFI, in the late cement, homogenised above $92^{\circ} \mathrm{C}$.

Interpretation: The Middle Cambrian sandstones in the Łeba Block contained HCFI in quartz cements, comprising brine and/or hydrocarbons (Jarmołowicz-Szulc, 2001a). One-phase aqueous, non-fluorescent inclusions occurred in the early cement, the oxygen isotopic compositions in formation water ranging from 20 to $28 \%$ SMOW (Jarmołowicz-Szulc 2001a), while crystallization conditions corresponded to low temperatures and precipitation from waters close to the meteoric water. High-temperature non-fluorescent two-phase fluid inclusions (AQFI) occur in the late quartz cement as veinlets, often cutting detrital grains and the intergranular space. Late cementation is interpreted as formed at temperatures of $\sim 100^{\circ} \mathrm{C}$ from waters with a heavier isotopic composition and of complex chemistry, when compared with meteoric waters. The fluorescent two-phase inclusions contained oil and were present either in the filling of veinlets cutting detrital grains, or in the less regular infills of micro-fissures. They are related to the late cementation stage. Fluid inclusions at the boundaries between detrital grains and authigenic quartz overgrowths have the same relationships. Co-trapping of brine and oil was interpreted as indicating formation conditions of $107^{\circ} \mathrm{C}$ and 317 bars (Jarmołowicz-Szulc, 2001a; Fig. 4B).

\section{ORDOVICIAN}

Results: In the borehole analysed (Płońsk IG 2/2A) located in central Poland (Fig. 1: area B), samples from $\sim 3500$ m depth contain calcite veins (medium and coarse grained calcite) with FI randomly distributed (Fig. 4C), in which no fluorescence was observed.

These inclusions were mostly brine-containing, showing homogenization in the interval from 145 to $152^{\circ} \mathrm{C}$ (Jarmołowicz-Szulc and Wołkowicz, 2018). The eutectic temperature is $\sim-46^{\circ} \mathrm{C}$. Melting temperatures $\mathrm{T}_{\mathrm{m}}$ between -4 and $-3.2^{\circ} \mathrm{C}$ point to a very low salinity of the fluid (5.3-6.5 wt.\% $\mathrm{NaCl}$ eq.). Some inclusions contain probable traces of methane gas with various contents of $\mathrm{CH}_{4}, \mathrm{CO}_{2}, \mathrm{O}_{2}$ and $\mathrm{H}_{2} \mathrm{~S}$.

The $\mathrm{Fl}$ in the coarse-grained calcite homogenized at higher temperatures. Their $T_{h}$ values fell into two temperature intervals of $197-226^{\circ} \mathrm{C}$ and $230-243^{\circ} \mathrm{C}$. $\mathrm{T}_{\mathrm{e}}$ varied from -39 to $-34^{\circ} \mathrm{C}$. Ice melting temperatures ranged from -13.2 to $-8.9^{\circ} \mathrm{C}$.

Interpretation: The homogenization temperatures differed while the fluids infilling the inclusions related to the calcite type in these Ordovician rocks. In the Płońsk IG 2/2A borehole, in the depth interval from 3522.15-3530.7, relatively high to low salinity brine fluids were trapped in coarse-grained carbonates (17.1 to 12.7 wt.\% NaCl eq.; Bodnar, 2003). They displayed high homogenization temperatures. Another type of brine was characterized by lower temperatures $\left(102-152^{\circ} \mathrm{C}\right)$ and contained vari- able amounts of methane, carbon dioxide, and oxygen. At least two flows of brine occurred: one of "pure" brine front, and one of a brine with some gases (Jarmołowicz-Szulc and Wołkowicz, 2018).

\section{DEVONIAN}

Results: In Devonian rocks from the depth interval 3748-3869 m, FI were analysed in calcite, dolomite and anhydrite cements from the boreholes Mełgiew-2 and Ciecierzyn-8 (Radlicz, personal communication, 1977; Jarmołowicz-Szulc, 1999b; Narkiewicz, 2011; Jarmołowicz-Szulc, 2015) located in the Lublin area (Fig. 1: area C). Ten Devonian samples were also analysed from the Giełczew IG 5 borehole occurring at shallower depth (as e.g., sample No 140, depth of $1955.2 \mathrm{~m}$, Radlicz, pers. comm., 1997). Inclusions are abundant, especially in dolomite, but small, down to $<1 \mu \mathrm{m}$ inclusions occur in the central parts of dolomite rhombohedral crystals while being almost absent from the outer rims. Larger inclusions $(2-5 \mu \mathrm{m})$ were observed in anhydrite and calcite. Rectangular FI are characteristic of anhydrite. These fluid inclusions are mono-phase and/or bi-phase displaying similar or different liquid to vapour ratios (Fig. 4D), and show no fluorescence.

Homogenization temperatures of the two-phase inclusions $(\mathrm{AQFI})$ ranged from 163 to $192^{\circ} \mathrm{C}$, the highest value being characteristic of stretched inclusions.

Eutectic temperatures of $<-21^{\circ} \mathrm{C}\left(-42^{\circ} \mathrm{C}\right.$ for dolomite and calcite, and $\sim-37^{\circ} \mathrm{C}$ for anhydrite) pointed to the presence of $\mathrm{Ca}$ and/or $\mathrm{Mg}$ ions together with $\mathrm{NaCl}$ (Shepherd et al., 1985). Temperatures close to $50^{\circ} \mathrm{C}$ corresponded to eutectic values characteristic of the $\mathrm{NaCl}-\mathrm{CaCl}_{2}-\mathrm{MgCl}_{2}-\mathrm{H}_{2} \mathrm{O}$ system

Interpretation: In the simple $\mathrm{NaCl}-\mathrm{H}_{2} \mathrm{O}$ system, ice melting temperatures of $\sim-10.1^{\circ} \mathrm{C}$ revealed a salinity of $14 \mathrm{wt} . \% \mathrm{NaCl}$ eq. (Brown, 1982; Bodnar, 2003). The fluids were brines $\mathrm{NaCl} / \mathrm{KCl}-\mathrm{H}_{2} \mathrm{O}$ (anhydrite) and/or $\mathrm{NaCl}-\mathrm{CaCl}_{2} / \mathrm{MgCl}_{2}-\mathrm{H}_{2} \mathrm{O}$ (calcite). No other fluids were observed.

\section{CARBONIFEROUS}

Fluid inclusions in Carboniferous rocks were studied from boreholes in the Lublin area (Fig. 1: area C; boreholes Stężyca 2, Maciejowice IG 1, Magnuszew IG 1; Kozłowska, 2004 , 2009; Kozłowska and Jarmołowicz-Szulc, 2009), in the western Baltic Sea area (Fig. 1: area D; boreholes K1-1/86, K9-1/89 and L2-1/87), and in the southwestern part of Poland in the Polish Lowlands (Jarmołowicz-Szulc and Wołkowicz, 2018; Fig. 1: areas E and F; boreholes Objezierze IG 1, Zakrzyn IG 1, Katarzy$\operatorname{nin} 2)$.

THE LUBLIN BASIN

Results: Homogenization temperatures of two-phase inclusions were different in different minerals. They were $84-138^{\circ} \mathrm{C}$ for calcite, $70-117^{\circ} \mathrm{C}$ for ankerite and $58-160^{\circ} \mathrm{C}$ for quartz (Fig. 4E, F). The inclusions contained brines. In the $\mathrm{H}_{2} \mathrm{O}-\mathrm{NaCl}$ system, fluids trapped in quartz in rock cements in the Lublin area showed salinity values ranging from 3.76 to 8.78 wt. $\% \mathrm{NaCl}$ eq. The density of the fluids was close to $1 \mathrm{~g} / \mathrm{cm}^{3}$. The eutectic temperatures were often close to $-30^{\circ} \mathrm{C}$ or even $-40^{\circ} \mathrm{C}$ in the carbonate cements, suggesting brine systems more complex than a simple $\mathrm{NaCl}-\mathrm{H}_{2} \mathrm{O}$ mixture, rather being mixtures such as $\mathrm{H}_{2} \mathrm{O}-\mathrm{NaCl}-\mathrm{CaCl}_{2}-\mathrm{MgCl}_{2}$ (Shephard et al., 1985; Bakker, 2003; Bodnar, 2003). The behaviour of several one-phase inclusions may indicate also other systems, such as $\mathrm{H}_{2} \mathrm{O}-\mathrm{CO}_{2}$ (Kozłowska and Jarmołowicz-Szulc, 2009). 

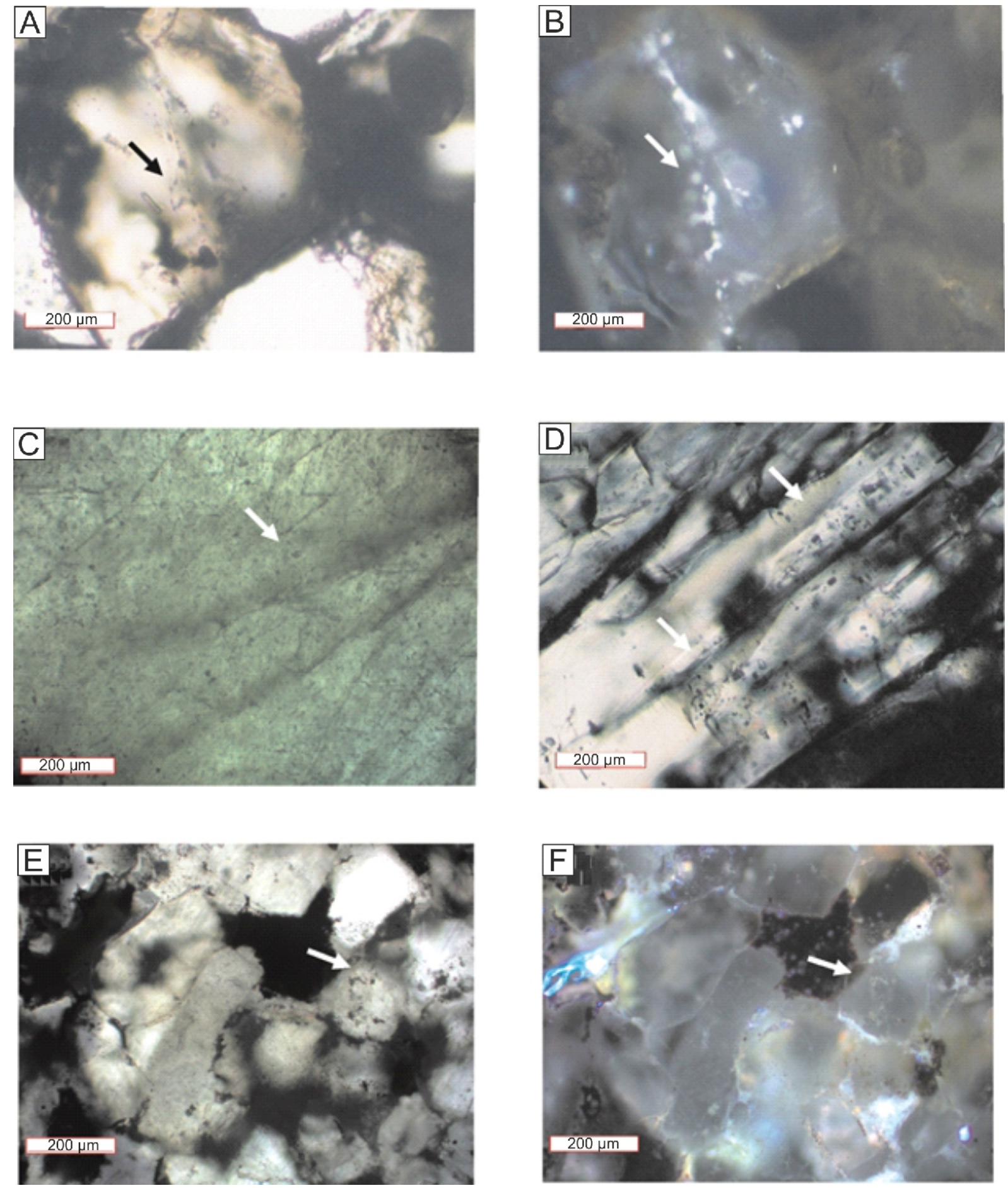

Fig. 4. Fluid inclusions in Cambrian, Ordovician, Devonian and Carboniferous rocks

A - quartz arenite, Middle Cambrian Baltic offshore, B3-9/95 borehole, depth $1415.5 \mathrm{~m}$, two-phase inclusions in late quartz infilling cutting some quartz grains, transmitted light; $\mathbf{B}$ - the same sandstone in fluorescence as in $\mathrm{A}$, inclusions displaying fluorescence in white-blue are filled with oil, reflected light, UV; C - fluid inclusions (brine) in calcite, Ordovician, Płońsk IG 2 borehole, depth 3500 m; D - fluid inclusions (brine) in anhydrite, Devonian, Giełczew IG 1 borehole, depth 1955.2 m; E - Upper Carboniferous sandstone, K-1-1/86 well, depth $3701.1 \mathrm{~m}$, inclusions in late quartz, transmitted light; $\mathbf{F}$ - the same sandstone in fluorescence, some fluorescing objects, reflected light, UV, Upper Carboniferous sandstone, K 1-1/86 well, depth 3701.1 m; arrows point to individual $\mathrm{FI}$ and FIAs 
Interpretation: Homogenization temperatures of fluid inclusions in Carboniferous rocks were in the interval $75-120^{\circ} \mathrm{C}$ for carbonate cements, and $100-110^{\circ} \mathrm{C}$ (maximum frequency interval) for quartz.

Brines trapped were of low salinity and displayed a density of $\sim 1 \mathrm{~g} / \mathrm{cm}^{3}$. Other, more complex fluids, e.g. $\mathrm{NaCl} / \mathrm{KCl}-\mathrm{CaCl}_{2} /$ $\mathrm{MgCl}_{2}-\mathrm{H}_{2} \mathrm{O}$ systems, were responsible for the formation of carbonate cements.

The results were close to those earlier given from the Lublin Coal Basin (Kozłowska, 2004, 2009), and showed analogy to those from other Carboniferous basins (e.g., Muchez et al., 1994).

\section{THE WESTERN BALTIC SEA AREA}

In the boreholes K1-1/86, K9-1/89 and L2-1/87 (offshore area, $\mathrm{N}$ from the Western Pomerania, Fig. 1: area D), Carboniferous rocks occur in the depth interval $\sim 3100$ to $3402 \mathrm{~m}$ (K1) and/or from 3242 to $3963 \mathrm{~m}$ (K9). Inclusions were observed in quartz and/or carbonate cements (Fig. 4E, F).

Results: In Carboniferous rocks from boreholes K1, K9 and L2 (Table 1), two-phase inclusions were very rare. Their homogenization temperatures varied (Jarmołowicz-Szulc, 2019). In general, they were $>90^{\circ} \mathrm{C}$. Inclusions in the quartz cement (authigenic "rims") in the K1 borehole (Fig. 4E, F) displayed $T_{h}$ $\sim 94-96^{\circ} \mathrm{C}$, while two-phase inclusions in the carbonate cements (dolomite, calcite) showed homogenization temperatures in the range of $168^{\circ} \mathrm{C}(\mathrm{K} 9)$ to $196.5^{\circ} \mathrm{C}(\mathrm{K} 1)$. Fluids present in inclusions in quartz were brines of moderate salinity (up to $\sim 10$ wt. $\% \mathrm{NaCl}$ eq.) of density between 0.984 and $1.015 \mathrm{~g} / \mathrm{cm}^{3}$. Fluids trapped in dolomite and calcite were more complex brines. Their eutectic temperatures of $\sim-40^{\circ} \mathrm{C}$ pointed to a more complex chemical system with $\mathrm{Mg} / \mathrm{Ca}$ ions, especially in the L2 sample from the depth of $2326.3 \mathrm{~m}$, the salinity of which was estimated at $15.08 \mathrm{wt} . \% \mathrm{NaCl}$ eq. with a density up to $1.071 \mathrm{~g} / \mathrm{cm}^{3}$.

Rare two-phase fluid inclusions assemblages (FIA) were observed close to the boundary of detrital and authigenic quartz in the sandstone from the $\mathrm{K} 1-1 / 86$ borehole at a depth of $3107.7 \mathrm{~m}$, and when cooled to $-70^{\circ} \mathrm{C}$ showed bubble division into two phases and bubble homogenization at $+23.1^{\circ} \mathrm{C}$. The whole inclusion homogenized at $96^{\circ} \mathrm{C}$. At the same depth, a one-phase inclusion showed homogenization at $\sim-82^{\circ} \mathrm{C}$. Possibly two-phase individuals $(\mathrm{L} 1+\mathrm{L} 2)$ present in the cements contained the same infill and characteristics.

Interpretation: Based on the analyses conducted, one and/or two-phase inclusions recognized in cements were filled with gas and/or brine, respectively (K1-1/86, K2-1/89 boreholes). The one-phase inclusions were filled with methane, most probably with some carbon dioxide.

In the $\mathrm{K} 1-1 / 86$ borehole, a $\mathrm{CO}_{2}$ density of $\sim 0.738 \mathrm{~g} / \mathrm{cm}^{3}$ in a bubble in an AQFI was calculated. Assuming $\mathrm{NaCl}-\mathrm{H}_{2} \mathrm{O}-\mathrm{CO}_{2}$ co-trapping, the $\mathrm{p}-\mathrm{T}$ conditions of entrapment were estimated using the method of crossed isochores, to be $\sim 480$ bar and $120^{\circ} \mathrm{C}$ (Fig. 2, A; $\mathrm{P}_{\mathrm{t}}, \mathrm{T}_{\mathrm{t}}$, respectively). The estimated density of the methane was $\sim 0.198 \mathrm{~g} / \mathrm{cm}^{3}$

\section{THE WIELKOPOLSKA AREA}

In the Wielkopolska area (Fig. 1: areas E and F), Carboniferous rocks occur at depths between 2432.3 and $2638.6 \mathrm{~m}$ (Katarzynin 2) and 4621.1-5090 m (Objezierze IG 1). These dark rocks contain carbonate veinlets.

Results: One and two-phase inclusions occur in small calcite veins (Katarzynin 2, depth $2588.45 \mathrm{~m}$ ). The two-phase, pseudo-secondary elongated inclusions form distinct assemblages (FIA). Groups of bright and dark shapeless one-phase inclusions were also observed, locally with a linear pattern. No fluorescence in UV was observed (Fig. 5A, B). The two-phase inclusions are filled with brine. Their homogenization temperatures are high $\left(T_{h} 207-233^{\circ} \mathrm{C}\right)$, and eutectic values are between -48.8 and $-38^{\circ} \mathrm{C}$. $\mathrm{T}_{\mathrm{m}}$ in the interval from -9.9 to $-6.5^{\circ} \mathrm{C}$ corresponds to medium fluid salinity, between $13.8-9.9 \mathrm{wt} . \% \mathrm{NaCl}$ eq. The one-phase $\mathrm{FI}$ were filled with methane with admixtures of $\mathrm{CO}_{2}$ or nitrogen (Kozłowska et al., 2021).

Small, bright, or grey two-phase fluid inclusions were seen in an anhydrite veinlet (Objezierze IG 1/4895.7). The volume of the gas phase is $\sim 15 \%$. The inclusions were mainly shapeless, some being oval. One-phase inclusions were also present. All inclusions either did not show fluorescence, or were "dull blue". Three two-phase inclusions that displayed yellow fluorescence were observed in the carbonate. They were filled with a fluid of slightly yellow colour when observed in transmitted light. The AQFI eutectic temperatures lay in the interval between -48 and $-33^{\circ} \mathrm{C}, \mathrm{T}_{\mathrm{m}}$ is from -7.5 to $-3^{\circ} \mathrm{C}$, indicating fluid salinity between 11 and 5.0 wt. \% $\mathrm{NaCl}$ eq. (Bodnar, 1992). $\mathrm{T}_{\mathrm{h}}$ values either exceeded $100^{\circ} \mathrm{C}$ or were $>250^{\circ} \mathrm{C}$. Some inclusions displayed a yellow fluorescence (Jarmołowicz-Szulc and Wołkowicz, 2018). In the Zakrzyn IG 1 borehole (depth $4788.3 \mathrm{~m}$ ) two-phase non-fluorescent inclusions occur in a coarse crystalline calcite vein and display $\mathrm{T}_{\mathrm{e}}$ close to $-49-(-42)^{\circ} \mathrm{C}$ and $/ \mathrm{or}-22^{\circ} \mathrm{C}$. Their $\mathrm{T}_{\mathrm{h}}$ values were measured in the interval from 137 to $190^{\circ} \mathrm{C}$; $\mathrm{Tm}$ lies between -6.3 to -0.7 .

Interpretation: One and/or two-phase inclusions occurred in calcite and were filled with gas and/or brine, respectively (Katarzynin 2, Objezierze IG 1, Zakrzyn IG 1). Those one-phase inclusions were filled with $\mathrm{CH}_{4}$, possibly with nitrogen, and most probably with some carbon dioxide (Raman spectra would be diagnostic here). Brine and traces of oil were found in anhydrite in the Objezierze IG 1 borehole. Given three types of brine inclusion, at least three different brine fluids occurred in the basin, as follows: low-salinity, medium temperature brine I - with only with a $\mathrm{NaCl} / \mathrm{KCl}$ component $\left(\mathrm{T}_{\mathrm{h}}\right.$ $\left.156-163^{\circ} \mathrm{C}\right)$; II - complex low-salinity brine $\left(T_{h} 206-233^{\circ} \mathrm{C}, T_{e}\right.$ from -48.8 to $-38^{\circ} \mathrm{C}, \mathrm{T}_{\mathrm{m}}$ from -9.9 to $-6.5^{\circ} \mathrm{C}$ ); III - moderate temperature and salinity fluid $\left(T_{h} 114^{\circ} \mathrm{C} ; T_{e}-33, T_{m}\right.$ ice $\left.-5.8^{\circ} \mathrm{C}\right)$.

The results of microthermometric analyses were sporadic in the Objezierze IG 1, at depth $4895.7 \mathrm{~m}$. The brine displayed moderate salinity, 11 and $5.0 \mathrm{wt} \% \mathrm{NaCl}$ eq. Higher hydrocarbons were present in the basin. A small admixture of gases of different composition might have occurred in some inclusions $\left(\mathrm{CH}_{4}, \mathrm{~N}_{2}, \mathrm{O}_{2}, \mathrm{H}_{2} \mathrm{~S}\right)$.

In the Zakrzyn IG 1 borehole (depth $4788.3 \mathrm{~m}$ ) brine inclusions in a coarsely crystalline calcite vein display salinity between 9.6 and $1.2 \% . \mathrm{NaCl}$ eq. (Bodnar, 2003) and probably contain a local gas admixture (methane, hydrogen sulphide).

\section{PERMIAN}

ROTLIEGEND

In the Paproć-Cicha Góra succession (Fig. 1: area F), the Rotliegend rocks studied occur at depths between 2627 and $2777.8 \mathrm{~m}$ (Table 1). Three types of infill of the pore space in the Rotliegend rocks were analysed: carbonates, quartz and sulphate cements (Maliszewska et al., 1997, 2003; Kuberska, 2004). Other than the FI studies, the calcite cements were also isotopically studied (Jarmołowicz-Szulc, 1999a, 2009).

Results: Fluid inclusions in the Rotliegend rocks from different boreholes have been widely analysed in the context of detailed petrological research (Maliszewska and Kuberska, 1996, 2009; Jarmołowicz-Szulc, 1997, 1999b) in the Wielkopolska area (Fig. 1: area F). Their characteristics may be summa- 

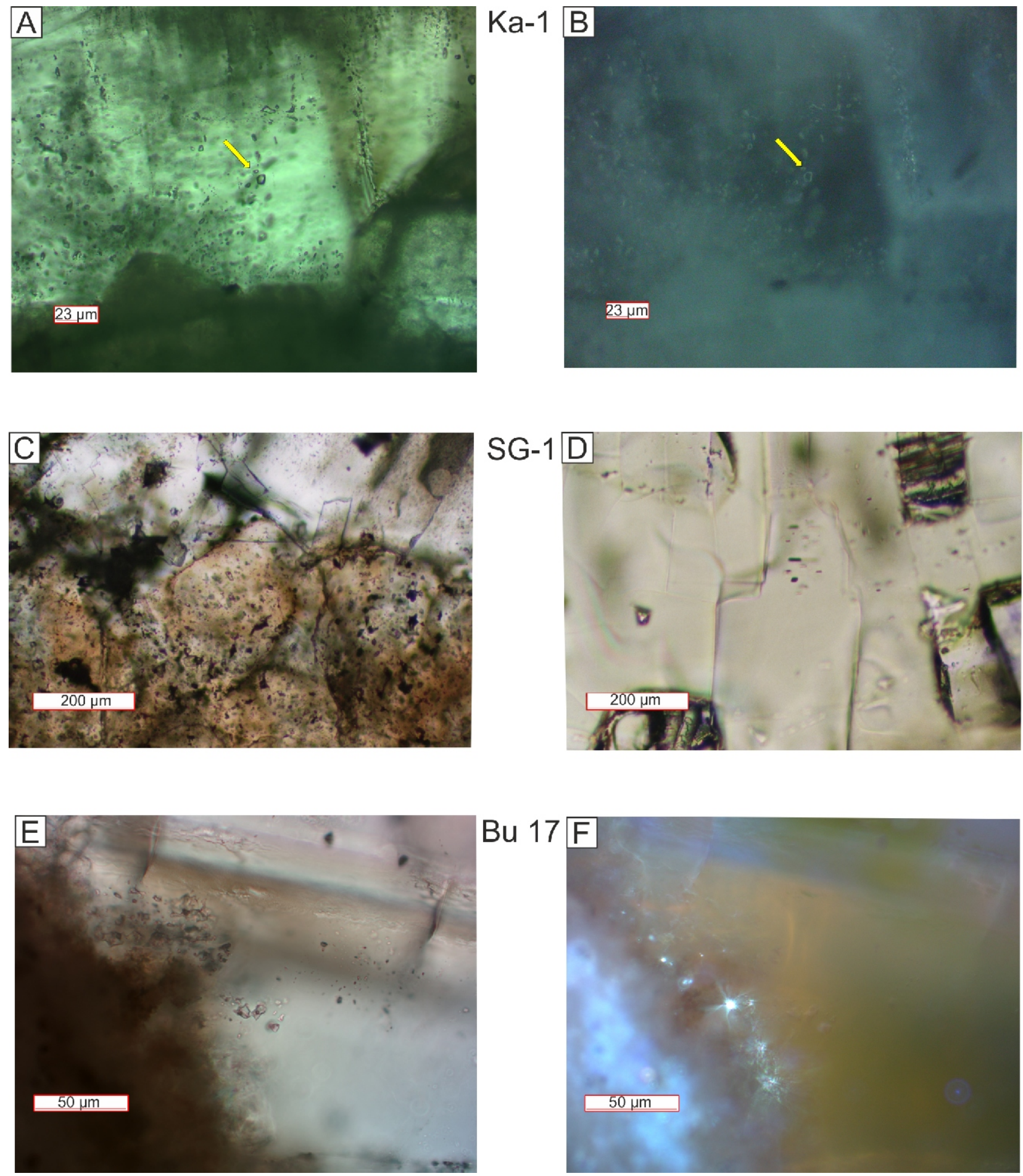

Fig. 5. Fluid inclusions in rocks from Carboniferous and Upper Permian basins

A - quartz arenite, Upper Carboniferous, Katarzynin 2 borehole (Ka-2), one-phase inclusions in quartz grains, transmitted light, arrow indicates methane inclusion; B - the same objects in fluorescence analysis, inclusions display no fluorescence, reflected light, UV, arrow shows the same methane inclusion as in A; C - fluid inclusions in calcite from the Sowia Góra 1 borehole (SG-1), depth 3256.34 m, transmitted light; D - fluid inclusions in anhydrite from the SG-1 borehole, depth $3256.34 \mathrm{~m}$, transmitted light; $\mathbf{E}$ - two-phase inclusion assemblage (FIA) in anhydrite in Zechstein carbonate rocks in the Buszewo 17 borehole, depth 3133.45 (Bu 17), transmitted light; F same inclusions as in E in fluorescence analysis, inclusions display white-blue fluorescence, reflected light, UV; arrows point to FI individuals or assemblages 
rised as follows: (1) inclusions were numerous in detrital grains, (2) some types of cements were not transparent and no inclusions can be observed within them, (3) if inclusions were present in the cement, they were generally scarce and small, (4) there was no observable pattern of distribution, abundance or characteristics of inclusions (Jarmołowicz-Szulc, 1999b).

Fluid inclusions in the Rotliegend rocks exhibited no fluorescence either in blue, or in ultraviolet light. Some minimum excitation ("dull-blue" colour, Jarmołowicz-Szulc, 1999a) was observed only in the case of the Paproć-Cicha Góra field, though not in the Rotliegend rocks, but in the Zechstein at the top of the geological section.

The Fls observed were primary and secondary, two- and one phase (Jarmołowicz-Szulc, 1999a). The liquid to gas phase ratio in two-phase inclusions varied in different types of cements, with a predominance of the liquid phase. The position of inclusions was often difficult to determine with reference to the cement due to a lack of meaningful relations with the crystallographic planes. No distinct primary assemblages were distinguished (sensu: FIA by Goldstein and Reynolds, 1994), only rare individual inclusions. One-phase inclusion assemblages displayed a secondary or pseudo-secondary character (Jarmołowicz-Szulc, 2009).

The inclusion habit in the Rotliegend rocks is various. Some inclusions were oval, some more or less regular in shape, others totally shapeless. The inclusions seen in anhydrite were rectangular, though randomly displayed in the crystal.

Interpretation: Primary two-phase inclusions were very rare in the carbonate, sulphate and quartz cements in the Rotliegend sedimentary rocks in the western part of the Polish Lowlands; the homogenization temperatures of the inclusions differed depending on the host mineral. They varied as follows: $100-130^{\circ} \mathrm{C}$ for anhydrite, $90-120^{\circ} \mathrm{C}$ for carbonate, and $131-133^{\circ} \mathrm{C}$ for quartz cements; the temperatures obtained for the inclusions did not correlate with the isotopic results, as shown by Jarmołowicz-Szulc (2009). Only the carbonate cements in the Paproć-Cicha Góra region displayed a co-incidence (Jarmołowicz-Szulc, 2015); the salinity of the brines was 2-10 wt.\% NaC eq., while eutectic temperatures between -30 and $-40^{\circ} \mathrm{C}$ suggested more complex chemical systems as, e.g., $\mathrm{H}_{2} \mathrm{O}-\mathrm{NaCl}-\mathrm{MgCl}_{2}$ - brines in the Paproć-Cicha Góra region had a density of $1 \mathrm{~g} / \mathrm{cm}^{3}$.

ZECHSTEIN

Some light hydrocarbons were observed in the anhydrite cements in the Paproć-Cicha Góra region in the uppermost, Zechstein, part of the borehole section (Jarmołowicz-Szulc, 1999). The hydrocarbon fluid trapped there is methane with some nitrogen admixture. The presence of methane in the cement may indicate the migration and trapping of gas as inclusions in the cement in Zechstein.

Two important oil-gas fields occur in the Zechstein rocks the Lubiatów and the Barnówko-Mostno-Buszewo fields (BMB, Górski and Trela, 1997; Wagner, 1998; Karnkowski 1999; Jaworowski and Mikołajewski, 2007). Kovalevich et al (2008) studied fluid inclusions in halite in the aureoles around oil and gas accumulations, including from the BMB.

$$
\text { THE LUBIATÓW FIELD }
$$

Results: Fluid inclusions were observed in carbonates, anhydrite and quartz, which either formed as cements, or fill fractures and fissures in laminated mudrocks (the Sowia Góra 1 borehole; Fig. 5C, D). The following types of inclusions were distinguished: one-phase (gas, brine), two-phase (brine), three-phase (water - light hydrocarbons/gas). Primary two-phase inclusions homogenized at temperatures between 68 and $132^{\circ} \mathrm{C}$, the highest values corresponding to stretched inclusions (Jarmołowicz-Szulc and Jasionowski, 2009). The eutectic temperatures vary from -56 to $-37^{\circ} \mathrm{C}$ for dolomite and calcite, and between -70 and $-56^{\circ} \mathrm{C}$ for anhydrite.

Fluid inclusions in calcite crystals displayed a characteristic distribution. The translucent inner grey part of the crystals is full of fluid inclusions while the outer part is bright, transparent, and almost without inclusions (Jarmołowicz-Szulc and Jasionowski, 2009; e.g., Sowia Góra 1, depth 3256.34 m, Fig. 5C). The homogenization temperatures also differed in those two parts of the crystals. The rare outer-part inclusions homogenized at $+68^{\circ} \mathrm{C}$, and those in the inner parts at $>70^{\circ} \mathrm{C}$ (Fig. 6B). In dolomite, two-phase brine inclusions homogenized at higher temperatures of $\sim 116.6^{\circ} \mathrm{C}$. One-phase inclusions - bright and/or dark - contained carbon dioxide and/or methane. Their $\mathrm{T}_{\mathrm{h}}$ was +8.0 and $-85^{\circ} \mathrm{C}$, respectively.

Ice melting temperatures were $\sim-15^{\circ} \mathrm{C}$ in the outer and from -6.0 to $-9.8^{\circ} \mathrm{C}$ in the inner parts of the crystals, indicating salinity that in the $\mathrm{NaCl}-\mathrm{H}_{2} \mathrm{O}$ system changes from 14 wt.\% $\mathrm{NaCl}$ eq. to 9-13 wt.\% NaCl eq. (Brown, 1982; Bodnar, 1992). Three types of inclusion occurred in the anhydrite. Two of them displayed a rectangular habit (Fig. 5D), were not stretched and varied in size and temperature. A population of smaller inclusions (3-4 $\mu \mathrm{m}$ in size) homogenized to liquid at $+106^{\circ} \mathrm{C}$, and the larger inclusions $(6-10 \mu \mathrm{m})$ at $+122^{\circ} \mathrm{C}$ (Jarmołowicz-Szulc and Jasionowski, 2009).

Interpretation: Eutectic temperatures of $<-21^{\circ} \mathrm{C}$ pointed to a presence of calcium and/or magnesium ions with $\mathrm{NaCl}$ (e.g., Goldstein and Reynolds, 1994). Eutectic temperatures of $-56^{\circ} \mathrm{C}$, and cotectic around $-40^{\circ} \mathrm{C}$ suggested complex $\mathrm{NaCl}-\mathrm{CaCl}_{2}-\mathrm{MgCl}_{2}-\mathrm{H}_{2} \mathrm{O}$ fluids with the presence of $\mathrm{CO}_{2}$, characterizing a chemical system of dissolved $\mathrm{Cl}^{-}, \mathrm{Ca}^{2+}, \mathrm{Mg}^{2+}, \mathrm{Na}^{+}$, and $\mathrm{Fe}^{2+}$ ions with carbon dioxide.

The dolomitization of $\mathrm{Ca} 2$ deposits in the Gorzów Wielkopolski region was related to reflux of strong evaporated marine waters at slightly increased temperatures. Fluid inclusions in quartz display a temperature interval of $70-100^{\circ} \mathrm{C}$ and high salinity. The isotopic composition of oxygen in the pore waters lay in the interval from +5 to $+10 \%$ (Jamołowicz-Szulc and Jasionowski, 2009). The fluid inclusion studies suggested that dedolomitization occurred during burial at temperatures of $\sim 100-120^{\circ} \mathrm{C}$

Another possible interpretation is that because the rocks/minerals studied occur at depths of $>3000 \mathrm{~m}$ and carbonates are susceptible to the influence of pressure and temperature, they may have crystallized from hot, saline waters (Aulstead et al., 1988).

THE BARNÓWKO-MOSTNO-BUSZEWO OIL AND GAS FIELD

Results: Temperature measurements were conducted for two-phase inclusions from different types of cement and different samples from boreholes at depths between $3121.6 \mathrm{~m}$ (B-7) and $3141.85 \mathrm{~m}$ (Bu-17; Fig. 5E, F) - Jarmołowicz-Szulc et al. (2020), Jarmołowicz-Szulc (2021). Inclusions were present in calcite, dolomite, anhydrite and fluorite.

Two-phase fluorescent HCFI in dolomite generally homogenized between 120 and $150^{\circ} \mathrm{C}$, with a frequency maximum of 128 and $138^{\circ} \mathrm{C}$ (Jarmołowicz-Szulc, 2021). The homogenization temperatures of brine inclusions in the dolomite were between 135 and $160^{\circ} \mathrm{C}$. There was a tendency for slightly higher values for AQFI than for $\mathrm{HCFI}$ in the same mineral. The eutectic temperatures for most non-fluorescent two-phase inclusions (aqueous) fell into the following intervals: -60 to $-50^{\circ} \mathrm{C}$ (dolo- 

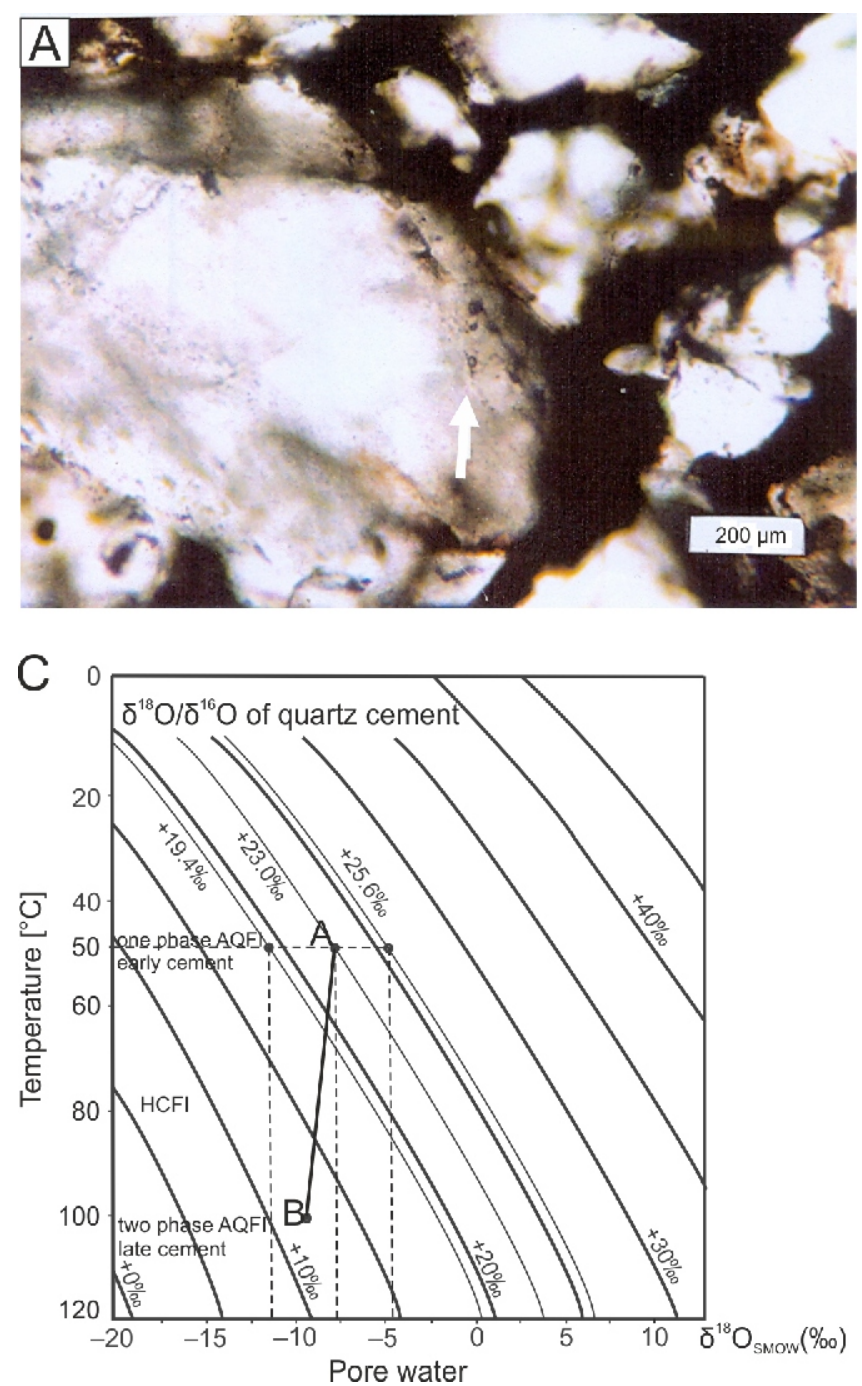

mite, calcite); -49 to $-47^{\circ} \mathrm{C}$ (anhydrite), and -40 to $-34^{\circ} \mathrm{C}$ (dolomite, quartz). The ice melting temperatures ranged from $-19^{\circ} \mathrm{C}$ to $-13^{\circ} \mathrm{C}$ for calcite and fan-like dolomite, $-6.5^{\circ} \mathrm{C}$ for mosaic dolomite, $-17.0^{\circ} \mathrm{C}$ for anhydrite, from -11.4 to $-7.8^{\circ} \mathrm{C}$ for dolomite, and from -6.8 to $-4.3^{\circ} \mathrm{C}$ for calcite.

Interpretation: Hydrocarbons (oil and/or gas) were trapped as inclusions in different types of cement in the rocks. Primary $\mathrm{HCFI}$ are abundant in the dolomite and the calcite, less frequent in anhydrite and fluorite; the presence of oil and/or gas in inclusions point to hydrocarbon migration in the area studied. The $\mathrm{HC}$-bearing inclusions relate to diagenetic processes i.e., they post-date the primary infill of the field. Brines trapped in inclusions vary in their chemical composition and salinity; primary brine $\mathrm{FI}$ accumulations in crystals (e.g., in calcite) pointed to a common hydrocarbon and brine front, while the secondary inclusions are a sign of hydrocarbon migration later than the formation of the cement studied. Assuming co-trapping of brine and oil in inclusions in the dolomite, P-T conditions estimated from crossed isochores were around $150-160^{\circ} \mathrm{C}$ and $400-420$ bars (Jarmołowicz-Szulc, 2021).

\section{DISCUSSION}

Based on this compilation of studies on fluid inclusions in minerals/rocks from different boreholes and wells from Poland (Fig. 1), some conclusions can be made regarding not only FI

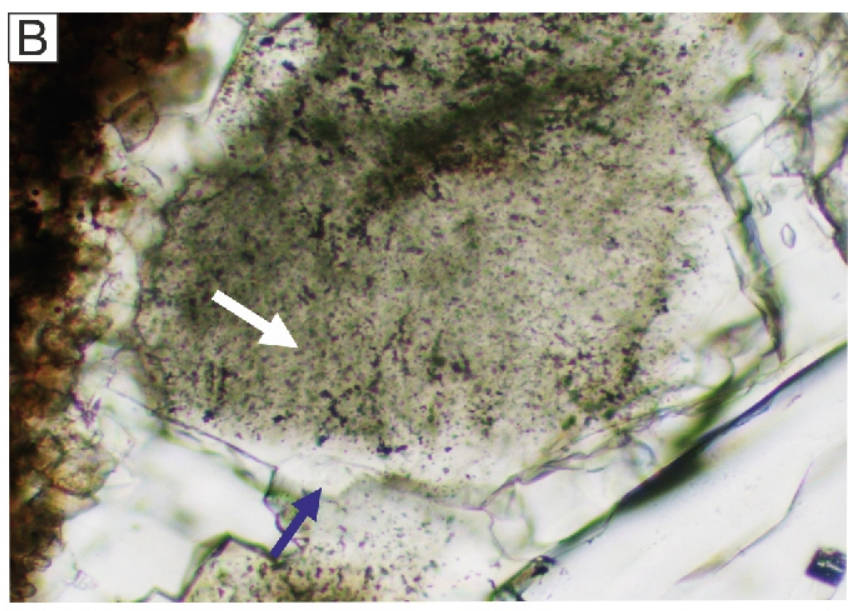

Fig. 6. Practical remarks and data interpretation

A - two-phase inclusions at the boundary of detrital and authigenic quarz (B3-1/95 borehole, Middle Cambrian sandstone), arrow points to individual $\mathrm{Fl} ; \mathbf{B}$ - fluid inclusion location in relation crystal - abundant FIA in calcite and individual in anhydrite (SG-1 borehole, depth $3256.34 \mathrm{~m}$, Zechstein carbonate), arrows point to abundant FIA in the inner part of the calcite crystal (white) and rare individuals in the outer part (black), length of white arrow $-200 \mu \mathrm{m}$; C - example of interpretation of isotopic results and fluid inclusion data (B3-1 borehole, Middle Cambrian sandstone, after Jarmołowicz-Szulc, 2001a)

characterization but also on basin evolution and their hydrocarbon migration, as discussed above.

\section{FLUID INCLUSION PETROGRAPHY}

Fluid inclusions in diagenetic minerals were not abundant and rather small in size (1-3 $\mu \mathrm{m}$, only occasionally $4-6 \mu \mathrm{m})$ which made it difficult to study the individual fluid inclusion by microthermometric analyses. Hydrocarbon inclusions, if present, were often much larger (to over a hundred $\mu \mathrm{m}$ ). Due to their fluorescence properties, they were easier to study both as regards localization in minerals and microthermometry. In turn, the methane-bearing inclusions displayed a variable size from $<1 \mu \mathrm{m}$ (beyond the limits of observation) to a few $\mu \mathrm{m}$. The first diagnostic feature was that they were one-phase and display no/dull blue fluorescence. However, only microthermometric observations via deep freezing and/or Raman spectra are really diagnostic, so the larger the inclusions, the better.

The small size of $\mathrm{FI}$ in some minerals locally generated problems in phase diagnosis of inclusions (one- or two-phase). In many places, however, inclusions were "readable", from the standpoint both of the number of their phases, and their position. Sometimes, fluid inclusions were better seen in petrographic thin sections than in double-sided polished FI sections where the cement could be in superposed over the grains of interest. It made sense, therefore, to conduct parallel observations. The more types of observation, the better the possibilities of meaningful interpretation. 
Inclusions displayed different shapes in different minerals. They ranged from irregular, shapeless to oval to more regular (Fig. 6A). The characteristic rectangular shape of two-phase individuals was observed in anhydrite (e.g., Fig. 5D).

Inclusions were either primary, pseudo-secondary, or secondary (cf. Roedder, 1984; Goldstein and Reynolds, 1994). They occurred either dispersed, or in distinct relation to the crystal habit (Fig. 6B), or they were present along healed fissures or fractures. FIAs in the sedimentary rocks were rare and contained only some inclusions.

As noted above, inclusions in minerals in the sedimentary rocks were one-phase, two-phase, or multiphase. The two-phase inclusions were the most obvious and they often were the only ones that could be examined by inexperienced researchers. It was, however, important not to disregard the one=phase $\mathrm{FI}$. One-phase inclusions, AQFI, were an indication of low-temperature mineral formation $\left(<50^{\circ} \mathrm{C}\right.$, as in, e.g., the early Cambrian quartz cements, Jarmołowicz-Szulc, 2001a; see also: Goldstein and Reynolds, 1994), or were methane-bearing, an important factor for geological interpretation and for hydrocarbon exploration.

Two phases of inclusions seen under the microscope may sometimes be a fake.

Generally, the two-phase AQFI contained liquid and vapour phases $(L, V)$. The liquid to vapour ratio was estimated and further studies based on this estimation were conducted. If the ratio was consistent for some inclusions, they formed an assemblage (FIA, sensu stricto: Goldstein and Reynolds, 1994), and were diagnostic as a FI group (Fig. 6B). An inconsistent ratio pointed to unstable conditions and further analytical results (if any) that need be treated carefully. Experience showed that the $\mathrm{FI}$ assemblages were not abundant. Often it was possible to deal only with individual fluid inclusions in the diagenetic cements, affecting the reliability of the results obtained.

\section{FLUORESCENCE PROPERTIES}

Hydrocarbon and aqueous inclusions may be trapped in a crystal during its growth and/or due to the healing of microfissures during the geologic history of the sedimentary ba$\sin$ (Roedder, 1984). The hydrocarbons fluoresce and their fluorescence colour in UV light may be used as a maturity indicator (McLimans, 1987; McLimans and Videvitch, 1987; Blamey et al., 2007). Fluorescence occurs due to the presence of fluorescing compounds called chromophores that influence emission e.g., in natural oils. The intensity of fluorescence is proportional to the concentration of chromophore accumulation and decreases with an increase in the number of chromophores (Atkins, 1982). The intensity of this luminescence increases towards longer wavelengths with an increase in aromatic rings in the molecule (Burrus, 1981). Fluorescence spectra have been widely used in the classification of the organic matter (Stasiuk 2002, and references therein) and for the characterization of its chemical composition and/or maturity (Nandakumar and Jayanthi, 2016, and references therein), and there is a relationship between a fluorescence colour of oil inclusions and oil maturity (Ping et al., 2019a, b, 2020, and references therein).

Fluorescence microscopy was used in this study to identify hydrocarbon fluid inclusions versus aqueous fluid inclusions, and also for differentiation of intracrystalline fissures filled with oil in oil-gas fields, This may be compared to data from e.g., Burrus et al. (1980, 1983); Burrus (1981); Burrus and Hath (1989); Munz (1995); Jarmołowicz-Szulc (2001a) and Jarmołowicz-Szulc et al. (2012).

Some authors have correlated fluorescence colours with API gravity values referred to oil densities (e.g., McLimans,
1987; Bodnar, 1990; Jarmołowicz-Szulc, 1998, 2001a; Stasiuk, 2002; Nandakumar and Jayanthi, 2016). Independent control is, however, needed since many factors can influence fluorescence, and the results of estimation of parameters, especially visual assessments, must be treated as just a first approximation (Jarmołowicz-Szulc, 1998, 2001b, 2017; Blamey and Ryder, 2009; Ping et al., 2020). Some researchers have stated that the determination of the chemical composition of fluorescing inclusions based on microfluorescence spectrometry is impossible (e.g., Pironon and Pradier, 1992). However, a quick and easy method of the author enabled some preliminary, non-destructive, and quick estimations of petroleum-bearing inclusions (Jarmołowicz-Szulc, 2016). This method used a simple graph, less complex than that reported by Przyjalgowski et al. (2005). As already underlined, such results should be treated as an approximation. However, it may be concluded that the higher the API degree, the larger the shift towards a white-blue colour emission in fluorescence (Fig. 7A). Some trends have been observed both from the results in the present paper and from published results (Pironon and Pradier, 1992; Jarmołowicz-Szulc 2001a; Stasiuk, 2002). For inclusions, a decrease in $L_{\max }$ and $Q$ occurred with an increase in total hydrocarbons and the concentration of saturated fractions. That agreed with the general results and conclusions from the Dongying depression (Ping et al., 2020). A progressive increase in $L$ max and $Q$ was correlated with an increase in aromatic hydrocarbons and concentrations of resins and asphaltenes. Nandakumar and Jayanthi (2016) also provided an empirical tool for predicting the APIG of oils and documented it on samples from a well in the Mumbai offshore basin, India. Fluorescence emission of oil in $\mathrm{HCFI}$ recorded by these authors was in the region of $406-720 \mathrm{~nm}$, i.e., wider than that shown in Figure 7 . The authors proposed inferring the APIG of unknown samples from an algebraic expression linking emission spectra to APIG for known crude oils. Figure 7 shows a compilation of the evaluation graph of Jarmołowicz-Szulc (2017; Fig. 7A) and the ideas of Nandakumar and Jayanthi (2016) using the author's data (Fig. 7B). To estimate the gravity of oil trapped in inclusions from the B graph, their red/green ratio must be known, i.e., fluorescence spectra must be available.

\section{FLUID INCLUSION MICROTHERMOMETRY}

Homogenization temperatures depend directly on the type of cement and on the borehole and indirectly on depth. They were different for calcite, dolomite, quartz, and anhydrite. Taking many factors into account, many useful pieces of information have been obtained from microthermometric measurements. Quartz has been most resistant to the influence of temperature and pressure, while minerals such as calcite and anhydrite are more susceptible to the influence of external factors. This is the microthermometric results for quartz have been considered the most reliable (compare also: Goldstein and Reynolds, 1994; Dudok and Jarmołowicz-Szulc, 1999, 2000). However, if microthermometry is combined with other data (isotopes, Raman, geochemistry), the composition and trapping conditions of (palaeo)fluids in the basin can be effectively characterized, and basin history too, as in the example shown in Figure 6C.

The eutectic temperature (first sign of melting) of $-21^{\circ} \mathrm{C}$ pointed to fluids in the $\mathrm{NaCl}-\mathrm{H}_{2} \mathrm{O}$ system. Temperatures $<-21^{\circ} \mathrm{C}$ were suggestive of the presence of calcium and/or magnesium ions together with $\mathrm{NaCl}$ in the brine (Roedder, 1984; Shepherd et al., 1985). Temperatures close to $-50^{\circ} \mathrm{C}$ suggested a complex fluid in the $\mathrm{NaCl}-\mathrm{CaCl}_{2}-\mathrm{MgCl}_{2}-\mathrm{H}_{2} \mathrm{O}$ system (Samson et al., 2003). 
A

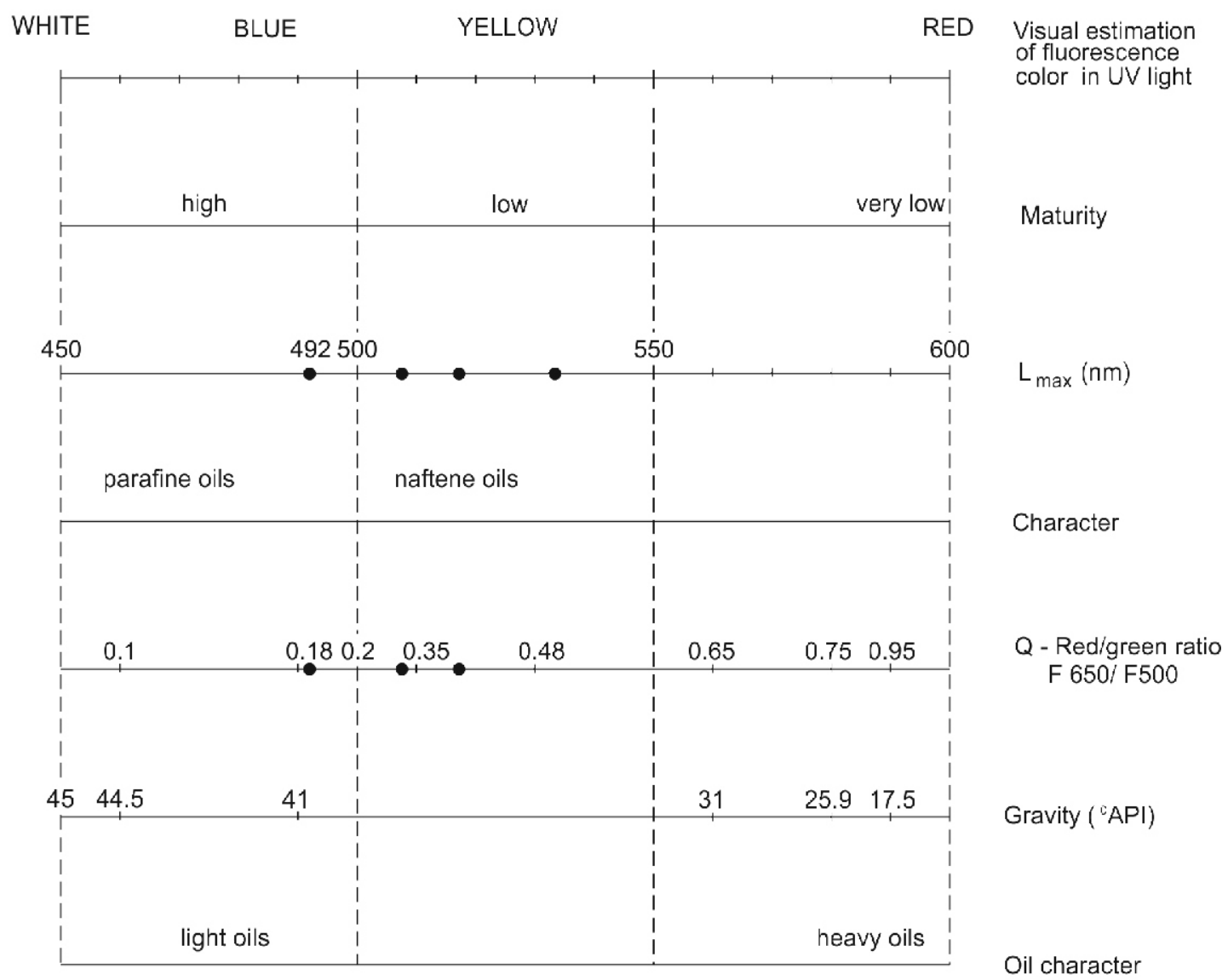

$\mathrm{B}$

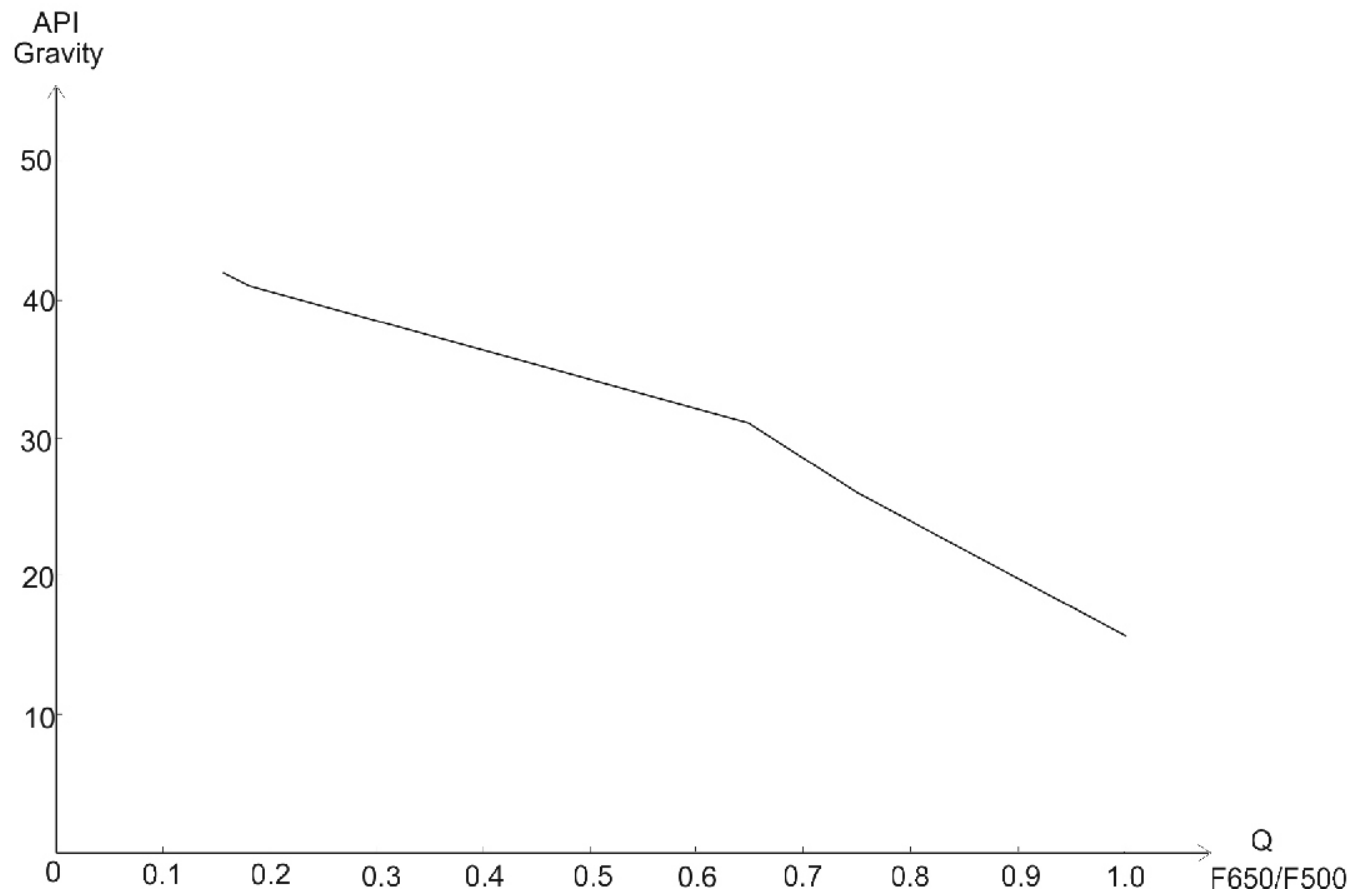

Fig. 7. Approximation of character of oil trapped in inclusions

A - graph based on data from Jarmołowicz-Szulc (2017); B - graph following the suggestions of Nanadakumar and Jayanthi (2016) 
In the simple $\mathrm{NaCl}-\mathrm{H}_{2} \mathrm{O}$ system, ice melting temperatures correspond to exact salinity values, in other systems, salinity might be expressed in weight percent $\mathrm{NaCl}$ equivalent (Brown, 1982; Bodnar, 1990; Bakker and Brown, 2003). If ratios of other components were known from other independent sources (e.g., from chemical analyses or Raman spectrometry), exact isochores may be constructed.

\section{FLUID INCLUSION COMPOSITION AND FLUID CHARACTERISTICS}

Multidirectional research conducted on fluid inclusions has allowed characterization of fluids trapped in inclusions with regard to their composition.

Fluids trapped in non-fluorescing inclusions were first of all brines of different compositions and salinities, as has been shown above. Densities of fluids were calculated based on microthermometric results (Brown, 1989; Bakker, 2003). Petroleum-bearing inclusions exhibited fluorescence under $366 \mathrm{~nm}$ UV and were generally easy to observe due to their excitation. The colour of fluorescence, however, may be discussed (see: Green et al., 2001; Ping et al., 2020). Inclusions that occur in small groups outlining growth zones and occasional isolated inclusions appear to be primary and therefore, were trapped during crystal growth. Many $\mathrm{HC}$ inclusions occur along healed microfractures that postdate crystal growth and are secondary. The relative separation in time between the formation of primary and secondary oil inclusions may sometimes not be very large when the associated primary and secondary aqueous inclusions show no distinction in homogenization temperature and salinity (Jensenius and Munksgaard, 1989). When primary and secondary oil inclusions have the same emission fluorescence colour, one can conclude that both types of inclusions have a similar composition (McLimans, 1987; Ping et al., 2020). The characteristics of oil based on fluorescence colours was roughly estimated using some general graphs (e.g., Nandakumar and Jayanthi, 2016; Jarmołowicz-Szulc, 2017; Fig. 7). The results, however, should be treated carefully and fluorescence spectra have to be known.

The composition of crude oil was established during generation and primary migration, but it may be strongly altered by different processes that can occur during secondary migration and accumulation. Biodegradation, water washing, phase separation, and transport in aqueous solutions can affect the distribution of hydrocarbons in the range of compounds from $\mathrm{C}_{1}$ (methane) to $\mathrm{C}_{35}$ (pentatriacontane) normally analysed in crude oils. Those processes have been widely described (e.g., Burruss and Hatch, 1989; Jensenius and Burruss, 1990; Peters et al, 2005). Fluorescence spectrometric analyses are important if one attempts to identify such nuances. Raman spectra can also be reliable, provided the spectrometer has a proper laser source for fluorescence studies (Nandakumar and Jayanthi, 2016). Otherwise it is only possible to analyse aqueous and/or methane-bearing inclusions (Frezzotti et al., 2012).

The methane-bearing inclusions were those evident as one phase at room temperature and, when deep frozen on the freezing-heating stage, they displayed homogenization down to $-82^{\circ} \mathrm{C}$ (Kleinrahm and Wagner, 1986). Shifts in the $T_{h}$ values pointed to admixtures such as, e.g., nitrogen and/or carbon dioxide. The exact composition of complex methane-bearing inclusions can be calculated from Raman spectra, as shown in Figure 3. However due to the small dimension of the inclusions, Raman analyses were possible only in some samples.

In sedimentary basins, the fluid systems often evolved from a $\mathrm{H}_{2} \mathrm{O}-\mathrm{NaCl} \pm \mathrm{KCl}$ type during the early stage of basin subsidence to $\mathrm{H}_{2} \mathrm{O}-\mathrm{NaCl}-\mathrm{CaCl}_{2}$ fluids during further burial (e.g., Jarmołowicz-Szulc, 2020; Jarmołowicz-Szulc et al., 2020). Lo- cally, fluid inclusions were enriched in $\mathrm{K}, \mathrm{Cs}, \mathrm{Li}, \mathrm{B}, \mathrm{Rb}$ and other cations, indicating intensive fluid-rock interaction of the saline brines with other rocks, e.g., Lower Permian volcanic rocks or deposits (Jarmołowicz-Szulc, 2021).

A different situation was recorded in fluid inclusions in fissure minerals hosted by Permian sandstones and carbonates: aqueous fluid inclusions in calcite, quartz, fluorite and anhydrite were $\mathrm{H}_{2} \mathrm{O}-\mathrm{NaCl}-\mathrm{CaCl}_{2}$-rich brines and showed homogenization temperatures between 120 and $180^{\circ} \mathrm{C}$. That corresponds to the brine chemistry of inclusions in halite as described by Kovalevych et al. (2008). Co-genetic gas inclusions trapped in the fissure minerals are generally much less frequent and small. When present, they showed variable $\mathrm{CH}_{4}-\mathrm{N}_{2}$ and no $\mathrm{CO}_{2}$. The entrapment of $\mathrm{CH}_{4}-\mathrm{N}_{2}$ inclusions may be related to phases of much later tectonic uplift (in the Late Cretaceous). Trapping conditions for brine and oil inclusions in dolomite in the $\mathrm{BMB}$ field estimated from crossed isochores were $\sim 150-160^{\circ} \mathrm{C}$ and $400-420$ bar, in agreement with the P-T reconstructions of low-pressure conditions during fluid entrapment, always $<500$ bar, indicated in north Germany by Lüders et al. $(2005,2008)$. As for the gas composition in inclusions, the inclusions presently studied differ from those in halite reported by Kovalevych et al. (2008) by lack of microthermometric evidence for $\mathrm{CO}_{2}$.

\section{GENERAL CONSIDERATIONS}

Based on the research conducted, it must be also concluded that the material studied material - cements of Paleozoic sedimentary rocks - was difficult from the standpoint both of fluid inclusion analyses and interpretation of results. This is connected with the factors influencing the inclusions. Deep burial may cause stretching and leakage of the FI (Goldstein and Reynolds, 1994; Bodnar, 1990; Samson et al., 2003). Inclusions trapped at low temperatures may be unstable due to heating during burial (Burrus, 1987; Goldstein and Reynolds, 1994). Under the influence of external factors, any pressure increase will cause brittle deformation of the inclusion walls followed by volume increase and finally, an increase of homogenization temperature. If we take the case of the inhomogeneous FI population in anhydrite from the Devonian rocks, the homogenization temperatures of $\sim 180^{\circ} \mathrm{C}$ may be an example of such process. However, another interpretation could be that the minerals crystallized from hydrothermal waters, as in Devonian rocks in Canada (Aulstead et al., 1988).

The fluid pressure within the Fls may decrease due to leakage caused by fracture/fissure formation. Such inclusions may be re-filled by formation waters that will change the temperature estimations. These do not show, therefore, the primary conditions in the basin. If no leakage symptoms are observed, however, ice melting temperature results $\left(T_{m}\right)$ may be considered reliable.

The rocks/minerals studied here have mostly been accessed by deep drilling. Sometimes, if the homogenization temperatures are compared with temperature data extrapolated from the borehole, the Fl estimated temperatures measured for two-phase inclusions are much lower than the respective borehole temperature values at the given depth. This may point to a continuous heating of inclusions due to increased temperatures. Many significant problems still exist in carrying out fluid inclusion studies and interpretation of the results.

The ice melting and homogenization temperatures of primary fluids may be altered because of re-equilibration during later processes (Roedder, 1984; Goldstein and Reynolds, 1994). Crystals formed in mixed fluids may display a large interval of ice melting temperature values corresponding to changes in fluid salinity. 
In other words, in sum, fluid inclusion microthermometric results must be treated carefully and interpreted only by taking a great deal of other data and results into account.

Raman spectroscopy has been used to successfully to analyse fluid inclusions with an increasing number of publications in recent years (e.g., Burruss, 2003; Frezzotti et al., 2012; Jarmołowicz-Szulc et al., 2012). No other technique can analyse liquid, gas and solid constituents, and so it is an important method for the analysis of geological fluids. There exist practical limitations to its use in minerals in sedimentary basins: the object studied must be relatively large, a rare condition in fluid inclusions in most diagenetic minerals; secondly, to analyse different materials with potentially fluorescing components, the spectrometer should be equipped with three different paralle laser sources, which is technically and financially difficult for many research centres, for without this no diagnostic results may be obtained for, e.g., $\mathrm{CH}_{4}$ since fluorescing objects nearby disturb the spectra.

\section{CONCLUSIONS}

Over 300 fluid inclusions have been studied in diagenetic minerals (quartz, calcite, fluorite, anhydrite) infilling pore space and/or fissures (quartz, calcite, fluorite, anhydrite) hosted by Paleozoic strata sampled by boreholes in the northern, central and south-eastern parts of Poland (Fig. 1), in order to decipher the fluids and potential hydrocarbon migration related to the particular basin. Microthermometric results for fluid inclusions revealed compelling evidence for multiple events of fluid migration. The results and values of different parameters obtained enabled the following general conclusions on fluid circulation and on the formation of minerals and bitumen in the different sedimentary basins of Poland.

1. Different types of fluids migrated through the sedimentary rocks. Heavy hydrocarbons (petroleum) were found trapped as inclusions in Cambrian, Ordovician, Carboniferous and Permian rocks. Light hydrocarbons (methane $+/$ - admixtures) have been detected in the Carboniferous and Zechstein basins.

2. In the Cambrian rocks, the brine fluid migration of aqueous chlorides occurred at the early or late stages of diagenesis, resulting in the formation of minerals infilling the pore space of quartz arenites and quartz wackes. The crystallization temperature of diagenetic quartz varied from $\sim 100$ to $\sim 150^{\circ} \mathrm{C}$. Hydrocarbon infill occurred at a later stage (Fig. 4A, B). Hydrocarbon formation and/or migration in the basin is reflected both by the presence of bitumen accumulations and by $\mathrm{FI}$ in minerals. P-T conditions estimated via isochore construction indicated fluid trapping at pressures between 300 and 500 bars and temperatures between 100 and $135^{\circ} \mathrm{C}$.

3. In the Ordovician rocks, fluids are trapped in rare inclusions in calcite containing brine of two types - of low and high salinity and homogenization temperatures of $\sim 150^{\circ} \mathrm{C}$ and $>200^{\circ} \mathrm{C}$, respectively. The low-salinity brines contained variable amounts of gases (methane and/or carbon dioxide). At least two episodes of brine fluid generation and migration occurred, one episode characterized by a "pure" brine $\left(\mathrm{NaCl}-\mathrm{H}_{2} \mathrm{O}\right)$ front and another episode of brine with variable gases $\left(\mathrm{NaCl}-\mathrm{CaCl}_{2} / \mathrm{MgCl}_{2}-\mathrm{H}_{2} \mathrm{O}\right)$.

4. In the Devonian basin, only brine fluids were present. They ranged in composition from $\mathrm{NaCl} / \mathrm{KCl}-\mathrm{H}_{2} \mathrm{O}$ in anhydrite to $\mathrm{NaCl}-\mathrm{CaCl}_{2} / \mathrm{MgCl}_{2}-\mathrm{H}_{2} \mathrm{O}$ brines in calcite. Homogenisation temperatures in carbonates lie in two groups: $75-115^{\circ} \mathrm{C}$ and $135-140^{\circ} \mathrm{C}$. Fluids displayed two ranges of salinity, namely between 7 and $10 \% \mathrm{NaCl}$ eq. and about $5 \% \mathrm{NaCl}$ eq.
5. In the Carboniferous basin, the fluid systems often evolved from $\mathrm{a}_{2} \mathrm{O}-\mathrm{NaCl} \pm \mathrm{KCl}$ type during the early stage of basin subsidence to $\mathrm{H}_{2} \mathrm{O}-\mathrm{NaCl}-\mathrm{CaCl}_{2}$ fluids during further burial. Fluid migration through Carboniferous strata was often accompanied by gas migration. The P-T entrapment conditions of $\mathrm{CO}_{2}$ and $\mathrm{NaCl}-\mathrm{H}_{2} \mathrm{O}$ were estimated to be $\sim 480$ bar and $120^{\circ} \mathrm{C}$ (Fig. 2A). Aqueous fluid inclusions in quartz from fissures in Carboniferous strata were commonly associated with co-genetically trapped $\mathrm{CH}_{4}-\mathrm{CO}_{2}$ inclusions. The P-T conditions estimated, via isochore construction, by Lüders et al. $(2005,2008)$ for an analogous and coeval basin in Germany indicated pressures oscillating between 620 and 1,650 bar and temperatures ranging between 170 and $300^{\circ} \mathrm{C}$ during fluid entrapment The migration of $\mathrm{CH}_{4}$-rich gases within the Carboniferous rocks may have been related to the main stage of basin subsidence and stages of basin uplift.

6. In the Zechstein basin, the fluid systems often evolved from a $\mathrm{H}_{2} \mathrm{O}-\mathrm{NaCl} \pm \mathrm{KCl}$ type during the early stage of basin subsidence to $\mathrm{H}_{2} \mathrm{O}-\mathrm{NaCl}-\mathrm{CaCl}_{2}$ fluids during further burial. Locally, fluid inclusions were enriched in $\mathrm{K}, \mathrm{Cs}, \mathrm{Li}, \mathrm{B}, \mathrm{Rb}$ and other cations, indicating intense fluid-rock interaction of the saline brines with Lower Permian volcanic rocks or strata. A different situation was recorded in fluid inclusions in fissure minerals hosted by Permian sandstones and carbonates: aqueous fluid inclusions in calcite, quartz, fluorite and anhydrite are $\mathrm{H}_{2} \mathrm{O}-\mathrm{NaCl}-\mathrm{CaCl}_{2}$-rich brines and show homogenization temperatures between 120 and $180^{\circ} \mathrm{C}$. Co-genetic gas inclusions trapped in the fissure minerals are generally much less frequent and small. When present, they showed variable $\mathrm{CH}_{4}-\mathrm{N}_{2}$ and no $\mathrm{CO}_{2}$. Their entrapment may be related to phases of much later tectonic uplift (in the Late Cretaceous). Trapping conditions for brine and oil inclusions in dolomite in the $\mathrm{BMB}$ field estimated from crossed isochores were $\sim 150-160^{\circ} \mathrm{C}$ and $400-420$ bar that are in agreement with the P-T reconstructions indicated in north Germany.

7. The hydrocarbon composition of crude oils trapped in $\mathrm{FI}$ had the potential to offer new insight into the history of fluid migration during oil generation, migration, and accumulation. Most petroleum inclusions were easily identified, within the paragenetic sequence of reservoir diagenesis and fracture filling, by fluorescence microscopy. Placing the occurrence of oil in the paragenetic sequence allowed "dating" of oil migration relative to diagenetic and tectonic events. It was important, however, to combine the $\mathrm{FI}$ results with bitumen parameters. The estimation of the composition of oil inclusions in authigenic minerals in strata was based on the visual fluorescence colours, but hydrocarbon-water and mineral-organic interactions may have affected the composition of the hydrocarbons observed in the samples. Moreover, assessments of the thermal maturity of oil inclusions using fluorescence characteristics should consider the possible impacts of biodegradation, water washing, gas-liquid phase separation and trapping fractionation on the fluorescence colours.

Acknowledgements. The research has been supported by the project of the Ministry of Science and Higher Education (PGI project No. 62.9012.1980.00.0). Two reviewers, S. George and the anonymous reviewer, are acknowledged for their critical comments, remarks and corrections, that significantly improved the paper. P. Modreski from USGS is kindly thanked for final language corrections. L. Skowroński assisted in drawing the figures. The journal editor D. Więcław is thanked for his suggestions. Last but not least, warm thanks are directed to V.H. Magalhäes whose perfect corrections and modification suggestions have had a real impact on the paper. 


\section{REFERENCES}

Anderson, T.F., Arthur, M.A., 1983. Stable isotopes of oxygen and carbon and their application to sedimentologic and paleoenvironmental problems. SEPM Short Course, 10: 1-151.

Aplin, C.A., McLeod, G., Larter, S.R., Pedersen, K.S., Soerensen, H., Booth, T., 1999. Combined use of Confocal Laser Scanning Microscopy and pVT simulation for estimating the composition and physical properties of petroleum in fluid inclusions. Marine and Petroleum Geology, 16: 97-110.

Atkins, P.W., 1982. Fluorescence. Physical Chemistry, 2nd edn. Oxford University Press.

Aulstead, K.L., Spencer, R.J., Krouse, H.R., 1988. Fluid inclusion and isotopic evidence on dolomitization, Devonian of western Canada. Geochimica et Cosmochimica Acta, 52: 1027-1035.

Bakker, R.J., 2003. Package FLUIDS 1. Computer programs for analysis of fluid inclusion data and for modelling bulk fluid properties. Chemical Geology, 194: 3-23.

Bakker R.J., Brown, P.E., 2003 - Computer modelling in fluid inclusion research. Short Course, Mineralogical Association of Canada, 32: 175-212.

Blamey, N., Ryder, A.G., Geddes, C.D., Lakowicz, J.R., 2007. Hydrocarbon fluid inclusion fluorescence: a review. In: Reviews in Fluorescence (eds. C.D. Geddes and J.R. Lakowicz). Springer.

Bodnar, R.J., 1990. Petroleum migration in the Miocene Monterey Formation, California, USA: constraints from fluid inclusion studies. Mineralogical Magazine, 54: 295-304.

Bodnar, R.J., 1992. Revised equation and table for freezing point depression of $\mathrm{H}_{2} \mathrm{O}$-salt fluid inclusions. PACROFI IV, Fourth Biennial Pan-American Conference on Research on Fluid Inclusions, Program and Abstracts, Lake Arrowhead, C.A., 4: 15.

Brown, P., 1982. Flincor: a microcomputer program for the reduction and investigation of fluid inclusion data. American Mineralogist, 74: 1390-1393.

Burruss, R.C., 1981. Hydrocarbon FI studies of sedimentary diagenesis. Short Course Mineralogical Association of Canada 6: $138-156$.

Burruss, R.C., 2003. Raman Spectroscopy of fluid inclusions. Short Course Mineralogical Association of Canada, 32: 279-289.

Burruss, R.C., Toth, D.J., Goldstein, R.H.,1980. Fluorescence microscopy of hydrocarbon fluid inclusions: relative timing of hydrocarbon migration events in the Arkoma Basin, N.W. Arkansas (abstract). EOS, 61: 400.

Burruss, R.C., Cercone, K.R., Harris, P.M., 1983. Fluid inclusion petrography and tectonic burial history of the Ali No2 well: evidence for timing diagenesis and oil migration, Northern Oman Foredeep. Geology 11: 567-570.

Burruss, R.C., Hatch, J.R., 1989. Geochemistry of oils and hydrocarbons source rocks, greater Anadarko basin: evidence for multiple sources of oils and long distance oil migration. Oklahoma Geological Survey Circulation, 90: 53-64.

Clayton, R. N., Mayeda, T., 1963. The use of bromine pentafluoride in the extraction of oxygen from oxides and silicates for isotopic analysis. Geochimica et Cosmochimica Acta, 27: 47-52.

Clayton, R.N., O'Neil, J.R., Mayeda, T.K., 1972. Oxygen isotope exchange between quartz and water. Journal of Geophysical Research, 77: 3057-3067.

Dudok, I.V., Jarmołowicz-Szulc, K., 2000. Hydrocarbon inclusions in vein quartz (the "Marmarosh diamonds") from the Krosno and Dukla zones of the Ukrainian Carpathians. Geological Quarterly, 44 (4): 415-424.

Dudok, I.V., Kotarba, M., Jarmołowicz-Szulc, K., 2002. Employment of the pyrolitic methods in geochemical studies of organic matter of vein formations (in Ukrainian with English summary) Geologiya i Geokhimya Goryuchikh Kopalin, 1: 1-15.

Durakiewicz, T., 1996. Electron emission control with pulsed heating of filament. International Journal Mass Spectrometry lon Processes, 156: 31-40.

Durakiewicz, T., Hałas, S.,1994. Triple collector system for isotope ratio mass-spectrometer. Inf. UMCS Report: 131-132.
Frezzotti, M.L., Tecce, F., Casagli, A., 2012. Raman spectroscopy for fluid inclusion analyses. Journal of Geochemical Exploration, 112: 1-20

George, S.C., Ruble, T.E., Dutkiewicz, A., Eadington, P.J., 2001 Assessing the maturity of oil trapped in fluid inclusions using molecular geochemistry data and visually-determined fluorescence colors. Applied Geochemistry, 16: 451-473.

Goldstein, R.H., Reynolds, T.J., 1994. Systematics of fluid inclusions in diagenetic minerals. SEPM Short Course, 31.

Goldstein, R.H., Rossi, D., 2002. Recrystallization in quartz overgrowths. Journal of Sedimentary Research, 72: 432-440.

Górski, M., Trela, M., 1997. Geometric system and estimation of properties of the reservoir series of the BMB oil field based on 3D seismic image (in Polish with English summary). Przegląd Geologiczny, 45: 685-692.

Hervig, R. L., Williams P., Thomas, R. M., Schauer, S. N., Steele, I.M., 1992. Microanalysis of oxygen isotopes in insulators by secondary ion mass spectrometry. International Journal Mass Spectrometry Ion Processes, 120: 45-63.

Jankowski, L., Jarmołowicz-Szulc, K., 2009. Particular tectonic zones (the mélange zones) as potential and significant paths for fluid migration and mineral formation. Mineralogical Review, 59: $31-44$

Jarmołowicz-Szulc, K., 1998. Quartz cements in the Cambrian sandstones, Żarnowiec region, N Poland: a fluid inclusion study. Geological Quarterly, 42 (3): 311-318.

Jarmołowicz-Szulc, K., 1999a. Badania izotopowe i inkluzji fluidalnych w cementach diagenetycznych złoża gazu Paproć-Cicha Góra (in Polish). Przegląd Geologiczny, 47: 476-477.

Jarmołowicz-Szulc, K., 1999b. Fluid inclusion systematics in the pore space fillings of the Paleozoic sedimentary rocks in Polish Lowlands (in Polish with English summary). Przegląd Geologiczny, 47: 542-546.

Jarmołowicz-Szulc, K., 2000. Mineralogiczno-geochemiczne środowisko tworzenia „diamentów marmaroskich" na podstawie badań inkluzji fluidalnych w minerałach żyłowych Karpat Zewnętrznych (in Polish). Archive materials Nr 2351/2000. Centralne Archiwum Geologiczne Państwowego Instytutu Geologicznego, Warszawa.

Jarmołowicz-Szulc, K., 2001a. Fluid inclusion studies on the quartz cements of the Middle Cambrian sandstones in the area of the Łeba Block in the Baltic Sea-diagenetic, isotopic and geochemical implications (in Polish with English summary). Biuletyn Państwowego Instytutu Geologicznego, 399: 1-90.

Jarmołowicz-Szulc, K., 2001b. Characteristic features of vein fillings in the southeastern part of the Polish Carpathians (calcite, quartz, bitumen) (in Polish with English summary). Przegląd Geologiczny, 49: 785-792.

Jarmołowicz-Szulc, K., 2009. Fluid inclusion analysis of pore space fillings in Rotliegend rocks in the selected regions of Polish Lowlands (in Polish with English summary). Przegląd Geologiczny, 57: 343-349.

Jarmołowicz-Szulc, K., 2015. Fluid inclusion analysis of minerals in sedimentary rocks - an overview and remarks (in Polish with English summary). Biuletyn Państwowego Instytutu Geologicznego, 464: 25-42.

Jarmołowicz-Szulc, K., 2016. Hydrocarbon inclusions in the cements of sedimentary rocks and vein minerals - characteristics and significance (in Polish with English summary). Biuletyn Państwowego Instytutu Geologicznego, 466: 87-101.

Jarmołowicz-Szulc, K., 2017. Estimation of oil characteristics: results based on fluorescence phenomenon and fluid inclusion synthesis and analysis. International Journal of Current Advanced Research, 6: 2014-2021.

Jarmołowicz-Szulc, K., 2019. Some elements of petrologic research within the BMB field (in Polish with English summary). Przegląd Geologiczny, 67: 161-164. 
Jarmołowicz-Szulc, K., 2021. Application of fluid inclusions to petroleum basin recognition: a case study from Poland. Minerals, 11.

Jarmołowicz-Szulc, K., Dudok, I.V., 2001. Vein minerals of Polish and Ukrainian Flysch Carpathians (in Polish with English summary). Przeglad Geologiczny, 49: 341-342.

Jarmołowicz-Szulc, K., Dudok, I.V., 2005. Migration of palaeofluids in the contact zone between the Dukla and Silesian units, Western Carpathians - evidence from fluid inclusions and stable isotopes in quartz and calcite. Geological Quarterly, $\mathbf{4 9}$ (3): 291-304

Jarmołowicz-Szulc, K., Jasionowski, M., 2009. Fluid inclusion and isotopic characterization of diagenetic minerals in the SG-1 borehole, W Poland, Abstract. European Current Research on Fluid Inclusions ECROFI XX,21-27.09.2009, Granada, Spain.

Jarmołowicz-Szulc, K., Wołkowicz, K., 2018. Analiza inkluzji płynów w otworach Objezierze IG 1, Zakrzyń IG 1, Katarzynin 2 , Kalisz IG 1 and Siedliska IG 1, Rówce 1, Łochów IG 1, Płońsk IG 2/2 i Darżlubie IG 1. Rozpoznanie stref perspektywicznych występowania węglowodorów niekonwencjonalnych, projekt PSG, etap II, raport końcowy (in Polish). Narodowe Archiwum Geologiczne PIG-PIB, Warszawa, 9051/2019.

Jarmołowicz-Szulc, K., Wołkowicz, K., 2019. New achievements in the mineral studies by use of the Raman microspectroscopy. Biuletyn Państwowego Instytutu Geologicznego, 474: 23-30.

Jarmołowicz-Szulc, K., Karwowski, Ł., Marynowski, L., 2012. Fluid circulation and formation of minerals and bitumens in the sedimentary rocks of the Outer Carpathians - based on studies on the quartz-calcite-organic matter association. Marine and Petroleum Geology, 32: 138-158.

Jarmołowicz-Szulc, K., Kozłowska, A., Kuberska, M., Matyasik, I., 2020. A petrological, mineralogical and geological study of the Main Dolomite in the Mo-1 borehole (in Polish with English summary). Przegląd Geologiczny, 68: 726, 780-793.

Jaworowski, K., 1997. Conditions of deposition of the Lower and Middle Cambrian sand bodies in the Polish part of the East-European (in Polish with English summary). Biuletyn Państwowego Instytutu Geologicznego, 377.

Jaworowski, K., Mikołajewski, Z., 2007. Oil- and gas-bearing sediments of the Main Dolomite (Ca2) in the Międzychód region: a depositional model and the problem of the boundary between the second and third depositional sequences in the Polish Zechstein Basin. Przegląd Geologiczny, 55: 1017-1024.

Jensenius, J., Burrus, R.C., 1990. Hydrocarbon-water interaction during brine migration: Evidence from hydrocarbon inclusions in calcite cements from Danish North Sea oil fields. Geochimica et Cosmochimica Acta, 54: 705-713.

Jensenius, J., Munkgaard, N.C., 1989. Large scale hot water migration systems around salt diapirs in the Danish Central Trough and their impact on diagenesis of chalk reservoir. Geochimica et Cosmochimica Acta, 53: 79-88.

Kalyuzhnyi, V.A., 1982. Principles of studies on mineral-forming fluids (in Russian). Naukova Dumka, Kiev.

Kalyuzhnyi, V.A., Sachno, B.E., 1998. Prospects for prognostics of the useful materials on the base of typomorphic features of the hydrocarbon and carbon dioxide fluid inclusions (in Russian). Geologia i Geokhimia Goryuchikh Kopalin, 3: 133-147.

Karnkowski, P., 1999. Oil and gas fields in the Carpathians and the Carpathian Foredeep. Oil and Gas deposits in Poland, 2: 245-253. "Geos" AGH, Kraków.

Kleinrahm, R., Wagner, W., 1986. Measurements and correlation of the equilibrium liquid and vapor pressure densities along the coexistence curve of methane. Journal of Chemistry, 18 730-760.

Kovalevych, V.M., Peryt, T.M., Shanina S.N., Wieclaw, D. Lytvyniuk, S.F., 2008. Geochemical aureoles around oil and gas accumulations in the Zechstein (Upper Permian) of Poland: Analysis of fluid inclusions in halite and bitumens in rock salt. Journal of Petroleum Geology, 31: 245-262.

Kozłowska, A., 2004. Diagenesis of the Upper Carboniferous sandstones at the boundary between the Lublin Graben and the War- saw Block (in Polish with English summary). Biuletyn Państwowego Instytutu Geologicznego, 411: 491-500.

Kozłowska, A., 2009. Diagenetic processes forming the pore space of the Carboniferous sandstones in the Lublin region (in Polish with English summary). Przegląd Geologiczny, 57: 335-342.

Kozłowska, A.J., Jarmołowicz-Szulc, K.L., 2009. Geochemica and mineralogical exploration of sandstones in the Lublin Carboniferous Basin, SE Poland. Proceedings of the 24th International Applied Geochemistry Symposium, Fredericton, New Brunswick, Canada, June 1-4, 2009, 1: 377-380.

Kuberska, M., 2004. Diagenesis of Rotliegend deposits in the Szczecinek-Bydgoszcz zone (Western Pomerania) (in Polish with English summary). Biuletyn Państwowego Instytutu Geologicznego, 411: 87-168.

Langford, F.F., Blanc-Valleron, M.M., 1990. Interpreting Rock-Eva pyrolisis data using graphs of pyrolisable hydrocarbons vs. total organic carbon. AAPG Bulletin, 74: 799-804.

Lüders, V., Reuther, C., Hath, P., Banks, D.A., Mingram (Plessen), B., Pettke,T., 2005. Fluid and gas migration in the $\mathrm{N}$ Germany Basin: fluid inclusions and stable isotope constraints. International Journal of Earth Sciences, 95: 990-1009.

Lüders, V., Plessen, B., Sippel, J., 2008. Fluid and gas migration in the western part of the Lower Saxony Basin (Germany) Geochimica et Cosmochimica Acta, 72: 12. Supplement 1 A572.

Maliszewska, A., Kuberska, M., 1996. Cementation of Rotliegend sandstones and their porosity and permeability (in Polish with English summary). Nafta-Gaz, 9: 365-373.

Maliszewska, A., Kuberska, M., 2009. On the isotopic studies of the diagenetic illite from the Rotliegend sandstones from Wielkopolska and Western Pomerania (in Polish with English summary). Przegląd Geologiczny, 57: 322-327.

Maliszewska, A., Kuberska, M., Kiersnowski, H., Jarmołowicz Szulc, K., Jackowicz, E., Langier-Kuźniarowa A., Borkowska B., 1997. Modele diagenezy osadów czerwonego spągowca w zachodniej części Niżu Polskiego (in Polish). Narodowe Archiwum Geologiczne PIG-PIB, 3/98, Warszawa.

Maliszewska, A., Kiersnowski, H., Kuberska, M., Sikorska, M., Jarmołowicz-Szulc, K., 2003. Skład ziarnowy eolicznych piaskowców czerwonego spagowca w Wielkopolsce i ich własności zbiornikowe (in Polish). Centralne Archiwum Geologiczne PIG-PIB, 2302/2003, Warszawa.

Marynowski, L., Zatoń, M., 2010. Organic matter from the Callovian (Middle Jurassic) deposits of Lithuania: compositions, sources and depositional environments. Applied Geochemistry, 25: 933-946.

Matyja, H., 2006. Stratigraphy and facies development of Devonian and Carboniferous deposits in the Pomeranian Basin and in the western part of the Baltic Basin and palaeogeography of the northern TESZ during late Palaeozoic (in Polish with English summary) Prace Państwowego Instytutu Geologicznego, 36: 79-122.

McLimans, R.K., 1987. The application of fluid inclusions to migration of oil and diagenesis in petroleum reservoirs. Applied Geochemistry, 2: 585-603.

McLimans, R.K., Videvitch, P.E., 1987. Reservoir diagenesis and oil migration, Middle Jurassic Great Oolite Limestone, Weldon basin, Southern England. In Petroleum Geology of North West Europe (eds. J. Brooks and K. Glennie): 419-429. Graham and Trodman.

Muchez, P., Marshall, J.D., Touret, J.L.R., Viaene, W.A., 1994. Origin and migration of paleofluids in the Upper Visean of the Campine Basin, northern Belgium. Sedimentology, 41 133-145.

Munz, I.A., Yardtey, B.W.D., Banks, D.A., Wayne, D., 1995. Deep penetration of sedimentary fluids in basement rocks from Norway: Evidence from hydrocarbon and brine inclusions in quartz veins. Geochimica et Cosmochimica Acta, 59: 239-254.

Nandakumar, V., Jayanthi, J.L., 2016. Hydrocarbon fluid inclusions, API gravity of oil, signature fluorescence emissions and emission ratios: an example from Mumbai Offshore, India. Energy Fuels, 30: 3776-3782. 
Narkiewicz, M., 2011. Lithostratigraphy, deposition systems and transgressive-regressive cycles of the Devonian in the Lublin Basin (in Polish with English summary). Prace Państwowego Instytutu Geologicznego, 196: 53-146.

Nawrocki, J., Becker, A., (eds.), 2020. Geological Atlas of Poland Państwowy Instytut Geologiczny, Warszawa.

O'Neil, J.R., 1979. Stable isotope geochemistry of rocks and minerals. In: Lectures in Isotope Geology (eds. E. Jäger and J.C Hunziker). 235-263. Springer-Verlag, Berlin.

Peters, K.E., Walters, C.C., Moldowan, J.M., 2005. The Biomarker Guide, 2nd ed. Cambridge University Press, Cambridge.

Ping, H., Chen, H., George, S.C., 2020. Quantitatively predicting the thermal maturity of paleo-oil trapped in fluid inclusions based on fluorescent and molecular geochemical data of oil inclusions in the Dongying Depression, Bohai Bay Basin. AAPG Bulletin, 104: 1751-1791.

Ping, H., Chen, H., George, S.C., Li, C., Hu, S., 2019a. Relationship between the fluorescence colour of oil inclusions and thermal maturity in the Dongying Depression, Bohai Bay Basin China: Part 1. Fluorescence evolution of oil in the context of hydrous pyrolysis experiments with increasing maturity. Marine and Petroleum Geology, 100: 1-19.

Ping, H., Chen, H., George, S.C., Li, C., Hu, S., 2019b. Relationship between the fluorescence color of oil inclusions and thermal maturity in the Dongying Depression, Bohai Bay Basin China: Part 2. Fluorescence evolution of oil in the context of petroleum generation, expulsion and cracking under geological conditions. Marine and Petroleum Geology, 103: 306-319.

Pironon, J., Pradier, B., 1992. Ultraviolet-fluorescence alteration of hydrocarbon fluid inclusions. Organic Geochemistry, 18: 501-509.

Podhalańska, T., Adamczak-Biały, T., Becker, A., Dyrka, I., Feldman-Olszewska, A., Głuszyński, A., Grotek, I., Janas, M., Jarmołowicz-Szulc, K., Jachowicz, M., 2018. Rozpoznanie stref perspektywicznych złóż niekonwencjonalnych węglowodorów w Polsce (in Polish). Projekt PSG, etap II, raport końcowy, Narodowe Archiwum Geologiczne PIG-PIB, Warszawa, 9051/2019.

Pożaryski, W., 1968. Podział obszaru Polski na jednostki tektoniczne (in Polish). Budowa Geologiczna Polski, 4. Niż Polski: 24. Wydawnictwa Geologiczne.

Przyjalgowski, M.A., Ryder, A.G., Glynn, T.J., 2005. Analysis of hydrocarbon-bearing fluid inclusions (HCFI) using time-re- solved fluorescence spectroscopy. Proceedings of SPIE 5826, Opto-Ireland 2005: Optical Sensing and Spectroscopy, 173 (July 14, 2005).

Radke, M., Welte, D.H., 1983. The Methylphenanthrene Index (MPI). A maturity parameter based on aromatic hydrocarbons. In: Advances in Organic Geochemistry 1981 (eds. M. Bjøroy, R. Pelet, J. Rullkötter and G. Speers): 504-512. J. Wiley and Sons, New York.

Radke, M., Welte, D.H., Willsch, H., 1986. Maturity parameters based on aromatic hydrocarbons: influence of the organic matter type. Organic Geochemistry, 10: 51-63.

Reynolds, T.J., 1993. Temperature calibration standards by SYNFLINC. Fluid Inc., Denver.

Roedder, E., 1984. Fluid inclusions. Reviews in Mineralogy, 12.

Samson, I., Anderson, A., Marshall, D. (eds.), 2003. Fluid inclusions. Mineralogical Association of Canada. Short Course, 32 : 1-374.

Shepherd, T.J., Rankin, A.H., Alderton, D.H.M., 1985. A Practical Guide to Fluid Inclusion Studies. Blackie, New York.

Sheppard, S.M.F., 1986. Characterization and isotopic variation in natural waters Reviews in Mineralogy, 16: 165-184.

Sikorska, M., 2000. Provenance petrological study of the Upper Vendian and Cambrian clastic material; foreland of the Pomeranian Caledonides (northern Poland). Geological Quarterly, 44 (3): 237-247.

Smith, J.T., 1994. Petroleum system logic as an exploration tool in a frontier setting. AAPG Memoir, 60: 25-49.

Stasiuk, L.D., 2002. Fluorescence microscopy and microspectrometry of $\mathrm{HCFI}$ and crude oils within Paleozoic. Geological Survey of Canada Open File 4369.

Volk, H., George, S.C., 2019. Using petroleum inclusions to trace petroleum systems - a review. Organic Geochemistry, 129: 99-123.

Wagner, R., 1998. Paleogeography of Zechstein. In: Palaeogeographic atlas of epicontinental Permian and Mesozoic in Poland 1:2500 000 (eds. R. Dadlez, S. Marek and J. Pokorski). Państwowy Instytut Geologiczny, Warszawa.

Williams, L., Hervig, R.L., Dutton, S.P., 1997. Constraints on paleofluid compositions in the Travis Peak Formation, East Texas: evidence from microanalyses of oxygen isotopes in diagenetic quartz. SEPM Special Publications, 57: 269-280. 